\title{
Tailor-Made Pentablock Copolymer Based Formulation for Sustained Ocular Delivery of Protein Therapeutics
}

\author{
Sulabh P. Patel, Ravi Vaishya, Gyan Prakash Mishra, \\ Viral Tamboli, Dhananjay Pal, and Ashim K. Mitra \\ Division of Pharmaceutical Sciences, School of Pharmacy, University of Missouri-Kansas City, HSB 5258, 2464 Charlotte Street, \\ Kansas City, MO 64108, USA \\ Correspondence should be addressed to Ashim K. Mitra; mitraa@umkc.edu
}

Received 2 February 2014; Revised 25 April 2014; Accepted 30 April 2014; Published 22 June 2014

Academic Editor: Philippe Maincent

Copyright (C) 2014 Sulabh P. Patel et al. This is an open access article distributed under the Creative Commons Attribution License, which permits unrestricted use, distribution, and reproduction in any medium, provided the original work is properly cited.

The objective of this research article is to report the synthesis and evaluation of novel pentablock copolymers for controlled delivery of macromolecules in the treatment of posterior segment diseases. Novel biodegradable PB copolymers were synthesized by sequential ring-opening polymerization. Various ratios and molecular weights of each block (polyglycolic acid, polyethylene glycol, polylactic acid, and polycaprolactone) were selected for synthesis and to optimize release profile of FITC-BSA, IgG, and bevacizumab from nanoparticles (NPs) and thermosensitive gel. NPs were characterized for particle size, polydispersity, entrapment efficiency, and drug loading. In vitro release study of proteins from NPs alone and composite formulation (NPs suspended in thermosensitive gel) was performed. Composite formulations demonstrated no or negligible burst release with continuous near zero-order release in contrast to NPs alone. Hydrodynamic diameter of protein therapeutics and hydrophobicity of PB copolymer exhibited significant effect on entrapment efficiency and in vitro release profile. CD spectroscopy confirmed retention of structural conformation of released protein. Biological activity of released bevacizumab was confirmed by in vitro cell proliferation and cell migration assays. It can be concluded that novel PB polymers can serve a platform for sustained delivery of therapeutic proteins.

\section{Introduction}

Diabetic retinopathy and age-related macular degeneration (AMD) are primary vision threatening ocular diseases which affect retinal pigment epithelium (RPE), macular region of the retina, choriocapillary, and Bruch's membrane. AMD is typically observed in two forms, "wet" and "dry." In wet $\mathrm{AMD}$, choroidal neovascularization (CNV) occurs due to the leakage of blood and other fluids into the subretinal space which leads to scar formation eventually causing irreversible vision loss [1]. Many investigators reported active involvement of vascular endothelial growth factor (VEGF), a naturally occurring lipoprotein in various pathophysiological processes including AMD and diabetic retinopathy (DR) [2]. Currently, anti-VEGF antibodies such as bevacizumab and ranibizumab are indicated for the treatment of wet AMD. Bevacizumab is a full-length $(149 \mathrm{kDa})$ recombinant humanized murine monoclonal antibody specific to all isoforms of VEGF [3]. Due to shorter intravitreal halflife of bevacizumab [4], current treatment requires frequent intravitreal injections to maintain therapeutic levels at retina/choroid. Frequent administrations are inconvenient and cause potential complications like retinal hemorrhage, retinal detachment, endophthalmitis, and more importantly patient noncompliance [5-7].

Various biodegradable polymeric nanoparticulate formulations have been extensively investigated for controlled delivery of protein therapeutics. Biodegradable polymers such as polycaprolactone (PCL), polylactic acid (PLA), polyglycolic acid (PGA), and polyethylene glycol (PEG) have been comprehensively studied for the preparation of protein-encapsulated nanoparticles (NPs). Recently, many investigators have applied various block copolymers such as PEG-PCL [8], PCL-PEG-PCL [9], poly lactide-co-glycolide (PLGA) [10], and PEG-PLA [11] for the development of sustained release protein formulations. However, previously 
published reports indicate that protein/peptide molecules suffer from rapid loss of biological activity during formulation preparation, storage, and/or release [12-15]. Acylation, with polymer degradation products (lactic acid and glycolic acid) [16, 17], accelerates hydrolysis due to lower $\mathrm{pH}$ caused by polymer degradation [18]. Moreover, presence of hydrophobic interfaces [19] is a potential reason for the loss of activity and/or irreversible aggregation of protein therapeutics inside the PLA, PLGA, PCL-PLA-PCL, and PLA-PEG-PLA based delivery systems. It is imperative to note that any change in protein/peptide structure, either physically or chemically, may cause immunogenicity and toxicity. A consecutive antibody response signifies safety concerns and subsequently restricts the efficacy of subsequent applications [20]. As a result, there is an urgency to develop biocompatible and biodegradable polymeric system which provides sustained release of protein therapeutics at near zero-order rate for longer periods without compromising stability and functional activity of proteins.

Therefore, the objective of this work is to synthesize and evaluate novel tailor-made PB copolymers for controlled and noninvasive delivery of protein macromolecules in the treatment of posterior segment diseases. We have synthesized novel biodegradable PB copolymers by sequential ring-opening polymerization. Various ratios and molecular weights of each block (PGA, PEG, PLA, and PCL) were selected for the synthesis to optimize sustained release profile of FITC-BSA, IgG, and bevacizumab from NPs and thermosensitive gel and combinations. Our hypothesis is that release of protein therapeutics from NPs is affected by their hydrodynamic diameters. Therefore, in this study, we have examined the effect of hydrodynamic diameter of protein molecule on entrapment efficiency and in vitro drug release. NPs have been characterized by particle size, polydispersity, entrapment efficiency, drug loading, and in vitro release profiles. Furthermore, in order to achieve continuous zero-order drug release, we have prepared and characterized a novel composite formulation comprising drug-loaded NPs suspended in thermosensitive gelling aqueous solution. Stability of released protein was also examined by $\mathrm{CD}$ spectroscopy and in vitro biological assays to ensure therapeutic efficacy of the protein.

\section{Materials and Methods}

2.1. Materials. Poly(ethylene glycol), (PEG: $1 \mathrm{kDa}$ and $4 \mathrm{kDa}$ ), methoxy-PEG $(550 \mathrm{Da})$, stannous octoate, $\varepsilon$-caprolactone, poly(vinyl alcohol) (PVA), and lipopolysaccharide were procured from Sigma-Aldrich (St. Louis, MO, USA). L-lactide and hexamethylenediamine (HMDI) were purchased from Acros organics (Morris Plains, NJ, USA). Micro-BCA was obtained from Fisher scientific. Mouse TNF- $\alpha$, IL-6, and IL$1 \beta$ ELISA kits were obtained from eBioscience Inc. Lactate dehydrogenase estimation kit and CellTiter $96 \mathrm{AQ}_{\text {ueous }}$ nonradioactive cell proliferation assay (MTS) kit were obtained from Takara Bio Inc. and Promega Corp., respectively. All other reagents utilized in this study were of analytical grade.

\subsection{Methods}

2.2.1. Synthesis of PB Copolymers. Novel PB copolymers, poly(glycolic acid)-poly(caprolactone)-poly(ethylene glycol) -poly(caprolactone)-poly(glycolic acid) (PGA-PCL-PEGPCL-PGA, i.e., PB-A), poly(lactic acid)-poly(caprolactone)poly(ethylene glycol)-poly(caprolactone)-poly(lactic acid) (PLA-PCL-PEG-PCL-PLA, i.e., PB-B), and poly(ethylene glycol)-poly(caprolactone)-poly(lactic acid)-poly(caprolactone)-poly(ethylene glycol), (PEG-PCL-PLA-PCLPEG, i.e., $\mathrm{PB}-\mathrm{C}$ ), were synthesized by ring-opening bulk polymerization method [21]. PB copolymers for preparation of NPs, i.e., PB-A and PB-B, were synthesized in two steps by sequential ring-opening polymerization. PEG $(1 \mathrm{kDa}$ and $4 \mathrm{kDa}$ ) was utilized as macroinitiator and stannous octoate was utilized as catalyst. In the first step, triblock (TB) copolymer PCL-PEG-PCL (Figure 1, Step 1) was synthesized by polymerization of $\varepsilon$-caprolactone on two open hydroxyl ends of PEG. In brief, PEG (1 g, $1 \mathrm{kDa}$ for PB-A) ( $2 \mathrm{~g}, 4 \mathrm{kDa}$ for PB-B) was dissolved in anhydrous toluene followed by distillation to remove residual moisture. $\varepsilon$-Caprolactone $(15 \mathrm{~g}$ for PB-A and $5.7 \mathrm{~g}$ for PB-B) and stannous octoate $(0.5 \%$ $\mathrm{w} / \mathrm{w}$ ) were added to anhydrous PEG and temperature was raised to $130^{\circ} \mathrm{C}$. After $24 \mathrm{~h}$, reaction mixture was dissolved in methylene chloride followed by precipitation in cold petroleum ether. The precipitated polymer was filtered and dried for $24 \mathrm{~h}$ under vacuum at room temperature. In the second step, PCL-PEG-PCL TB copolymer was reacted with glycolide and L-lactide to prepare PB-A (Figure 1, Step 2) and PB-B (Figure 2) copolymers, respectively. TB copolymer and glycolide $(0.6 \mathrm{~g}) / \mathrm{L}$-lactide $(3.45 \mathrm{~g})$ were added in round bottom flask and temperature was raised to $130^{\circ} \mathrm{C}$ under inert atmosphere. To this reaction mixture, stannous octoate $(0.5 \%$ $\mathrm{w} / \mathrm{w}$ ) was added and reaction was allowed to run for $24 \mathrm{~h}$. PB copolymer was then purified by cold ether precipitation method as described in the first step. The polymer was dried under vacuum and stored at $-20^{\circ} \mathrm{C}$ until further use.

For the synthesis of thermosensitive gelling polymer, TB copolymer (mPEG-PCL-PLA) was synthesized by ring-opening bulk copolymerization as described above (Figure 3). $\varepsilon$-Caprolactone $(8.25 \mathrm{~g}$ ) was polymerized at the hydroxyl terminal of mPEG $(550 \mathrm{Da}, 5.5 \mathrm{~g})$ followed by another polymerization with L-lactide $(2.75 \mathrm{~g})$. Resulting TB copolymers were coupled utilizing HMDI (equimolar of $\mathrm{mPEG}$ ) as a linker. Coupling reaction was carried out at $70^{\circ} \mathrm{C}$ for $8 \mathrm{~h}$. Polymers were purified by cold ether precipitation followed by drying under vacuum and stored at $-20^{\circ} \mathrm{C}$.

2.2.2. Characterization of Polymers. Synthesized polymers were characterized by molecular weight and purity by ${ }^{1} \mathrm{H}$ NMR spectroscopy and gel permeation chromatography (GPC).

${ }^{1} \mathrm{H}$-NMR Analysis. To perform ${ }^{1} \mathrm{H}-\mathrm{NMR}$ spectroscopy, polymeric materials were dissolved in $\mathrm{CDCI}_{3}$ and spectra were recorded with Varian-400 NMR instrument. Purity and molecular weight $(\mathrm{Mn})$ were calculated from the ${ }^{1} \mathrm{H}$-NMR spectra. 


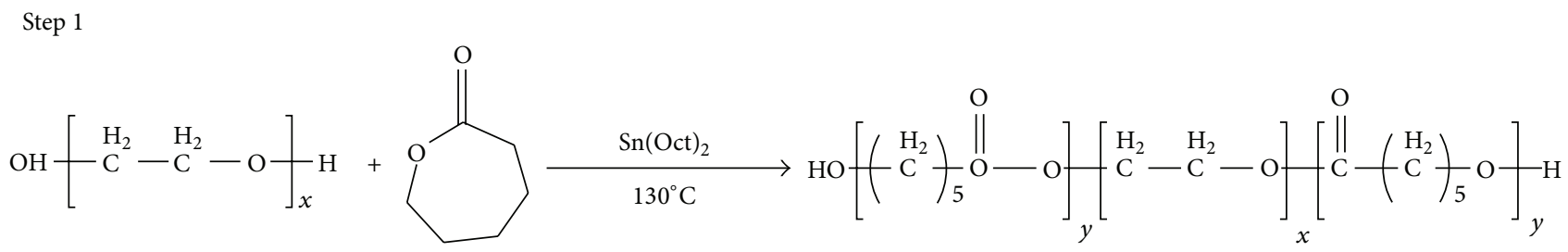
PEG

Step 2

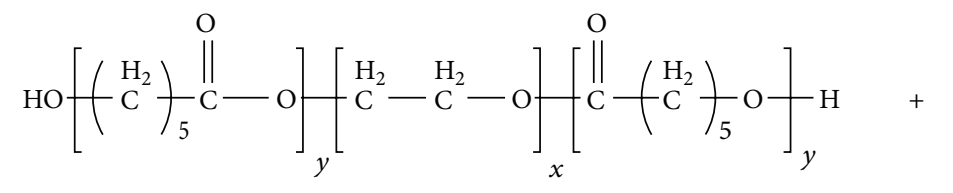

HO-PCL-PEG-PCL-OH

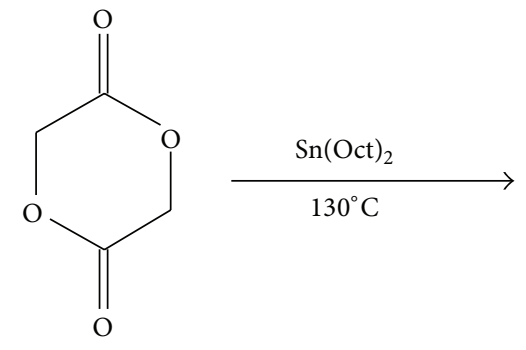

Glycolide

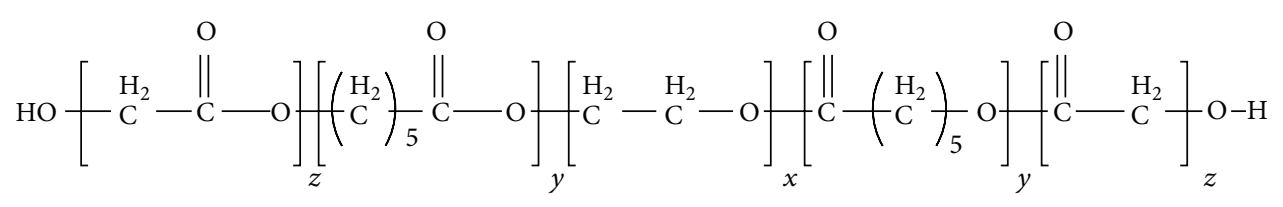

PGA-PCL-PEG-PCL-PGA

FIgURE 1: Synthesis scheme for PB-A (PGA-PCL-PEG-PCL-PGA) copolymer.

GPC Analysis. Purity, molecular weights, and polydispersity of PB copolymers were further confirmed by GPC analysis. Polymeric samples were analyzed with refractive index detector (Waters 410). Briefly, samples were prepared by dissolving $5 \mathrm{mg}$ of polymeric material in tetrahydrofuran (THF) whereas THF was utilized as eluting agent at the flow rate of $1 \mathrm{~mL} / \mathrm{min}$. Separation was carried out on Styragel HR3 column. Polystyrene samples with narrow molecular weight distribution were considered as standards.

\subsubsection{In Vitro Cytotoxicity Studies}

Cell Culture. Human retinal pigment epithelial cells (ARPE19) were cultured and maintained according to the previously published protocol from our laboratory [22]. In brief, cells were cultured in Dulbecco's Modified Eagle's Medium (DMEM)/F-12 medium containing 10\% fetal bovine serum (FBS), $15 \mathrm{mM}$ of HEPES, $29 \mathrm{mM}$ of sodium bicarbonate, $100 \mathrm{U} / \mathrm{L}$ of penicillin, and $100 \mathrm{mg} / \mathrm{L}$ of streptomycin. A mouse macrophage cell line, RAW-264.7, was cultured and maintained in DMEM supplemented with 10\% FBS, $100 \mathrm{U} / \mathrm{L}$ of penicillin, and $100 \mathrm{mg} / \mathrm{L}$ of streptomycin. The Statens Seruminstitut rabbit corneal (SIRC) cell line was selected between passages 410 and 425 . This cell line was grown with cell culture media composed of MEM containing 10\% FBS, lactalbumin, HEPES, sodium bicarbonate, $100 \mathrm{U} / \mathrm{L}$ of penicillin, and $100 \mathrm{mg} / \mathrm{L}$ of streptomycin. Human conjunctival epithelial cells (HCEC) were maintained in cell culture flask containing MEM Earle's BSS medium supplemented by $10 \%$ FBS, $100 \mathrm{U} / \mathrm{L}$ of penicillin, $100 \mathrm{mg} / \mathrm{L}$ of streptomycin, $29 \mathrm{mM}$ of sodium bicarbonate, and $2 \mathrm{mM}$ L-glutamine. Choroidretinal endothelial cells (RF/6A cells) were cultured and maintained in cell culture medium composed of RPMI-1640 comprising 10\% FBS, $100 \mathrm{U} / \mathrm{L}$ of penicillin, and $100 \mathrm{mg} / \mathrm{L}$ of streptomycin [23]. All five cell lines were procured from ATCC and maintained according to ATCC guideline at $37^{\circ} \mathrm{C}$, $5 \% \mathrm{CO}_{2}$, and $95 \%$ humidity.

Lactate Dehydrogenase (LDH) Assay. Previously published protocol with minor modification was employed to evaluate the cytotoxicity of $\mathrm{PB}$ copolymers [24]. Briefly, $10 \mathrm{mg} / \mathrm{mL}$ of $\mathrm{PB}$ copolymers (PB-A and PB-B) was dissolved in ACN and $100 \mu \mathrm{L}$ of solutions was aliquoted in each of the 96well plates. Plates were exposed overnight under UV light (laminar flow) for polymer sterilization as well as evaporation of ACN. ARPE- 19 cells at a density of $1.0 \times 10^{4}$ were seeded in each well and incubated at $37^{\circ} \mathrm{C}$ and $5 \% \mathrm{CO}_{2}$ in humidified atmosphere for $48 \mathrm{~h}$. After completion of incubation period, cell supernatants were analyzed for quantification of $\mathrm{LDH}$. Absorbance of each well was estimated at $450 \mathrm{~nm}$ by 96 -well plate reader. More than $10 \%$ of LDH release was considered 
Step 2<smiles>[Y]C(C)(C)OC(=O)C(C)(C)CC(=O)C(C)(C)C(=O)C(C)(C)CC(C)(C)OC(C)(C)CC(C)(C)O</smiles><smiles>CC1OC(=O)C(C)OC1=O</smiles>

HO-PCL-PEG-PCL-OH

$$
\downarrow
$$

$\mathrm{Sn}(\mathrm{Oct})_{2}$

$130^{\circ} \mathrm{C}$

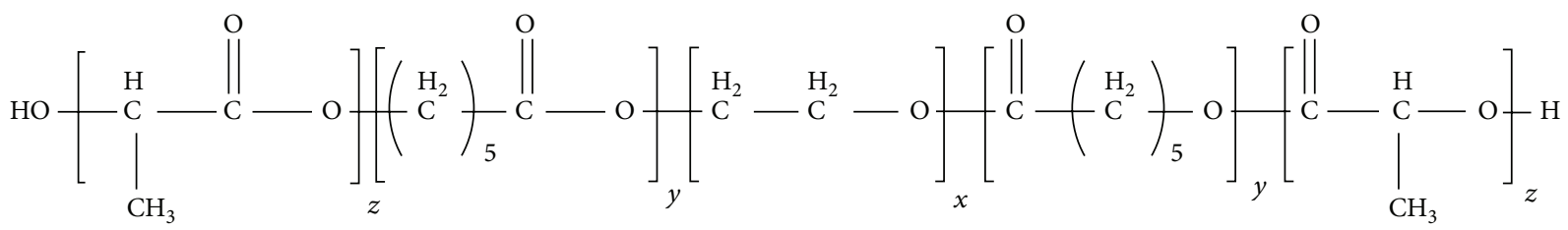

PLA-PCL-PEG-PCL-PLA

Figure 2: Synthesis scheme for PB-B (PLA-PCL-PEG-PCL-PLA) copolymer. Note: for synthesis of PB-B Step 1 was similar as described in Figure 1.

as cytotoxic. To evaluate cytotoxicity of block copolymers on conjunctiva, cornea, and macrophages, similar experiment was performed with HCEC, SIRC, and RAW-264.7 cells. LDH release (\%) was calculated according to

\section{$\mathrm{LDH}$ release $(\%)$}

$$
\begin{aligned}
& =\frac{\text { Abs. of Sample }- \text { Abs. of negative control }}{\text { Abs. of positive control }- \text { Abs. of negative control }} \\
& \quad * 100 .
\end{aligned}
$$

MTS Assay. Safety and biocompatibility of PB copolymers were further established by performing in vitro cell viability assay (MTS assay) [25]. This assay was performed according to previously reported protocol with minor modifications. As described earlier, PB copolymers solutions at the concentration of $10 \mathrm{mg} / \mathrm{mL}$ were prepared, aliquoted, and sterilized. After sterilization, ARPE-19 cells were seeded in each well of 96-well plates at a cell density of $1.0 \times 10^{4}$ and incubated at $37^{\circ} \mathrm{C}$ and $5 \% \mathrm{CO}_{2}$ in humidified atmosphere for $48 \mathrm{~h}$. At the end of incubation period, cell culture medium was aspirated and cells were incubated for $4 \mathrm{~h}\left(37^{\circ} \mathrm{C}\right.$ and $\left.5 \% \mathrm{CO}_{2}\right)$ in presence of $100 \mu \mathrm{L}$ of serum-free medium containing $20 \mu \mathrm{L}$ MTS solution. Absorbance of each well was estimated at $450 \mathrm{~nm}$. Similar procedure was repeated with other ocular and macrophage cell lines such as HCEC, SIRC, and RAW264.7 cells. Percent cell viability was calculated according to

Cell viability (\%)

$$
\begin{aligned}
& =\frac{\text { Abs. of Sample }- \text { Abs. of negative control }}{\text { Abs. of positive control }- \text { Abs. of negative control }} \\
& \quad * 100 .
\end{aligned}
$$

In this study, PB copolymers which exhibited more than $90 \%$ of cell viability were considered nontoxic and suitable for ocular applications.

2.2.4. In Vitro Biocompatibility Studies. PB copolymers were dissolved in ACN at the concentration of $10 \mathrm{mg} / \mathrm{mL}$. Two hundred $\mu \mathrm{L}$ was aliquoted in each well of 48-well cell culture plates which were incubated overnight under UV lights (laminar flow) for ACN evaporation and sterilization of resulting polymer film. After sterilization, RAW-264.7 cells $\left(5.0 \times 10^{4}\right)$ were seeded in each well of cell culture plate and incubated for $24 \mathrm{~h}$ at $37^{\circ} \mathrm{C}$ and $5 \% \mathrm{CO}_{2}$. Cell supernatants were analyzed for the presence of cytokines, that is, TNF$\alpha$, IL-6, and IL-1 $\beta$. Lipopolysaccharide (LPS) was utilized as positive control whereas cells without treatment were considered as negative control. Cytokines were measured by ELISA method according to manufacturer's instructions. Standard calibration curves for TNF- $\alpha$, IL-6, and IL- $1 \beta$ were 


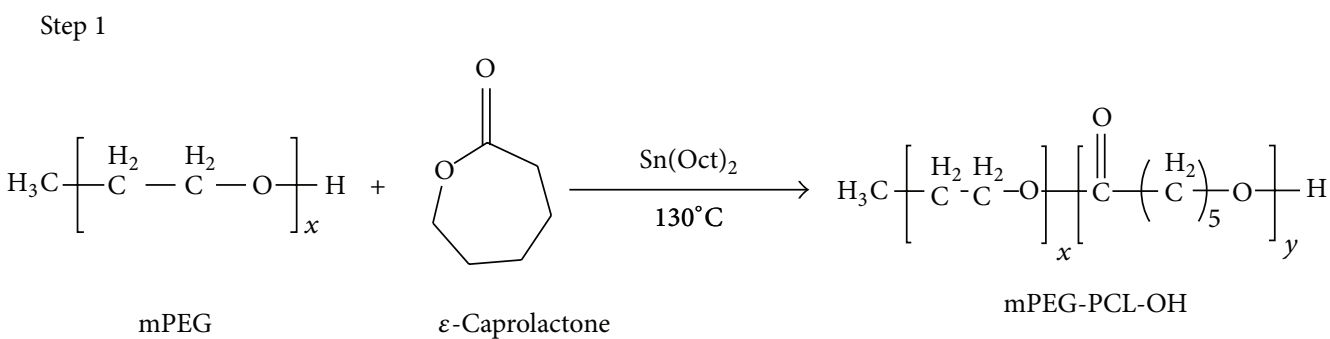

Step 2

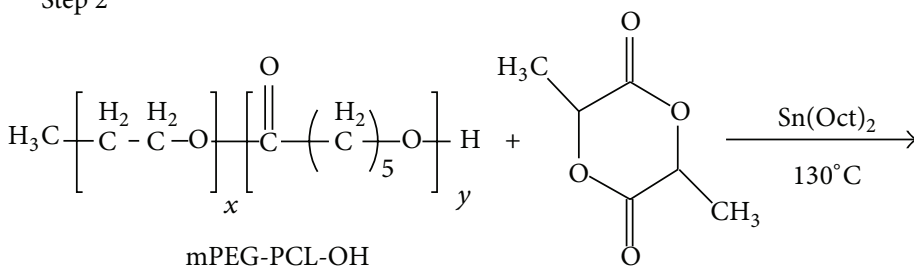

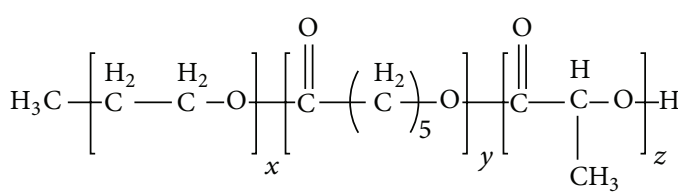

mPEG-PCL-PLA

$$
\text { Helactide } \quad \text { HMDI } 70^{\circ} \mathrm{C}
$$

Figure 3: Synthesis scheme for PB-C (PEG-PCL-PLA-PCL-PEG) copolymer.

prepared in ranges of $10-750 \mathrm{pg} / \mathrm{mL}, 5-500 \mathrm{pg} / \mathrm{mL}$, and $10-$ $500 \mathrm{pg} / \mathrm{mL}$, respectively.

2.2.5. Preparation of Nanoparticles. IgG-loaded PB NPs were prepared by $\mathrm{W}_{1} / \mathrm{O} / \mathrm{W}_{2}$ double emulsion solvent evaporation method [26]. Briefly, predetermined quantity of IgG (10 mg) was dissolved in $0.1 \mathrm{M}$ phosphate buffer saline (PBS, $\mathrm{pH} 7.4$ ) $(1 \mathrm{~mL})$ containing $50 \mu \mathrm{L}$ of Tween-80 ( $\mathrm{W}_{1}$ phase). In order to prepare organic phase, $100 \mathrm{mg}$ of $\mathrm{PB}$ copolymer was solubilized in $4 \mathrm{~mL}$ of dichloromethane (DCM) containing $50 \mu \mathrm{L}$ of Span-20 (organic phase). Primary emulsion $\left(\mathrm{W}_{1} / \mathrm{O}\right)$ was prepared by dropwise addition of $\mathrm{W}_{1}$ phase to the organic phase under constant sonication applied with probe-sonicator for $1 \mathrm{~min}$ at $4 \mathrm{~W}$ output. To avoid excessive heating and possible degradation of protein, preparation of emulsion was carried out in ice-bath. Resulting $\mathrm{W}_{1} / \mathrm{O}$ primary emulsion was then added dropwise in $20 \mathrm{~mL}$ of $2 \%$ polyvinyl alcohol (PVA) solution $\left(\mathrm{W}_{2}\right.$ phase) under constant sonication for $4 \mathrm{~min}$ at $5 \mathrm{~W}$ output. Double emulsion $\left(\mathrm{W}_{1} / \mathrm{O} / \mathrm{W}_{2}\right)$ was stirred at room temperature for $30 \mathrm{~min}$ followed by evaporation of DCM under low pressure. Once DCM was evaporated, NPs were centrifuged for $30 \mathrm{~min}$ at $20000 \mathrm{rpm}$ and $4^{\circ} \mathrm{C}$ followed by two washing cycles with distilled deionized water (DDW). Finally, IgG-loaded NPs were freeze-dried in presence of 5\% mannitol (cryoprotectant) and stored at $-20^{\circ} \mathrm{C}$ until further use. NPs were prepared with two $\mathrm{PB}$ copolymers, that is, $\mathrm{PB}-\mathrm{A}$ and PB-B. A similar protocol was followed to prepare FITCBSA and bevacizumab-loaded NPs. NPs were characterized by particle size, entrapment efficiency (EE\%), drug loading (DL\%), and in vitro drug release pattern.

\subsubsection{Characterization of Nanoparticles}

Particle Size and Polydispersity. Freeze-dried NPs were dispersed in DDW $(1 \mathrm{mg} / \mathrm{mL})$ and analyzed for their size and distribution. Particle size was determined by Zeta sizer (Zetasizer Nano ZS, Malvern Instruments Ltd., Worcestershire, $\mathrm{UK})$ at $90^{\circ}$ scattering angel. All the NP samples were analyzed in triplicate.

Entrapment Efficiency (EE) and Drug Loading (DL). Proteinencapsulated freeze-dried NPs were evaluated for the estimation of entrapment efficiency (EE) and drug loading (DL). EE was estimated by the amount of protein in the supernatants obtained from NP preparation. Micro-BCA protein estimation kit was employed for estimation of total protein. For analysis of DL, $2 \mathrm{mg}$ equivalent protein-loaded 
NPs was dissolved in $200 \mu \mathrm{L}$ of dimethyl sulfoxide (DMSO). Resulting solutions were analyzed by UV absorbance spectroscopy. Standard curve of respective proteins (IgG, FITCBSA, and bevacizumab) ranging from 31.25 to $2000 \mu \mathrm{g} / \mathrm{mL}$ was prepared in DMSO. Following equations were utilized for the calculation of EE (\%) and DL (\%):

EE (\%)

$$
=\left(1-\frac{\text { Amount of drug in supernatant }}{\text { Total amount of drug }}\right) * 100 \text {, }
$$

DL (\%)

$$
=\left(\frac{\text { Amount of drug in nanoparticles }}{\text { Total amount of drug and polymer }}\right) * 100 \text {. }
$$

In Vitro Release Studies. IgG-loaded NPs were further characterized by their ability to sustain drug release. In order to conduct in vitro drug release studies, $1 \mathrm{mg}$ of IgG equivalent freeze-dried NPs was suspended in $1 \mathrm{~mL}$ of PBS ( $\mathrm{pH} 7.4$ ). Resulting NP suspension was then incubated in water bath equilibrated at $37^{\circ} \mathrm{C}$. At predefined time intervals, the suspension was centrifuged at $13000 \mathrm{rpm}$ for $30 \mathrm{~min}$. A $200 \mu \mathrm{L}$ supernatant was collected and replaced with the same volume of PBS. NPs were then resuspended and release study was continued at $37^{\circ} \mathrm{C}$. In a second set of in vitro release studies, $1 \mathrm{mg}$ equivalent IgG containing NPs was suspended in $500 \mu \mathrm{L}$ of aqueous solution of thermosensitive gelling polymer (PBC) $(20 \mathrm{wt} \%)$. Resulting suspension was incubated in $10 \mathrm{~mL}$ vial at $7^{\circ} \mathrm{C}$ for $30 \mathrm{~min}$. Once gel was formed, an aliquot $(5 \mathrm{~mL})$ of PBS (preincubated at $37^{\circ} \mathrm{C}$ ) was slowly added. At predetermined time intervals, $1 \mathrm{~mL}$ of clear supernatant was collected and replaced with the same volume of fresh PBS (preincubated at $37^{\circ} \mathrm{C}$ ). Release samples were analyzed by Micro-BCA for total protein content according to supplier's instructions. FITC-BSA and bevacizumab-loaded NPs were also evaluated for in vitro release kinetics. Samples of released FITC-BSA were analyzed by fluorescence spectroscopy with excitation and emission wavelengths of $490 \mathrm{~nm}$ and $525 \mathrm{~nm}$, respectively. In vitro release experiments were performed in triplicate and expressed as cumulative drug released (\%) with time.

2.2.7. Release Kinetics. In order to delineate release mechanism, release data was fitted to five different kinetic models described below.

Korsmeyer-Peppas equation is as follows:

$$
\frac{M_{t}}{M_{\infty}}=k t^{n}
$$

where $k$ is the kinetic constant and $n$ is the diffusion exponent which describes release mechanism. $M_{t}$ and $M_{\infty}$ represent cumulative protein release at time $t$ and at the equilibrium, respectively.

Higuchi equation is as follows:

$$
Q_{t}=K t^{1 / 2}
$$

where $K$ denotes Higuchi rate kinetic constant, $Q_{t}$ is the amount of released protein at time $t$, and $t$ is time in hour.

Hixson-Crowell equation is as follows:

$$
C_{0}{ }^{1 / 3}-C_{t}{ }^{1 / 3}=k t
$$

where $C_{0}$ and $C_{t}$ represent initial and remaining amounts of protein in formulation, respectively, $k$ is the constant incorporating surface to volume ratio, and $t$ is time in hour.

First-order equation is as follows:

$$
\log C=\log C_{0}-\frac{K t}{2.303},
$$

where $K$ denotes the first-order rate constant, $C_{0}$ is the initial protein concentration, and $t$ represents time in hour.

Zero-order equation is as follows:

$$
C=K_{0} t
$$

where $K_{0}$ is the zero-order rate constant and $t$ is time in hour.

2.2.8. Stability of IgG. Released IgG was analyzed by CD spectroscopy to examine secondary structure. CD analysis was carried out at room temperature with Jasco 720 spectropolarimeter. CD spectra were recorded between wavelengths of 200 and $250 \mathrm{~nm}$ at scanning speed of $5 \mathrm{~nm} / \mathrm{min}$ utilizing $1 \mathrm{~cm}$ cell. CD measurements were reported as molar ellipticity $[\theta]$. CD spectrum of PBS was utilized as blank.

\subsubsection{Stability Study of Bevacizumab by In Vitro Biological Assays}

Cell Proliferation Assay. A cell proliferation assay (MTS) was performed according to previously published protocols with minor modifications [27-29]. Briefly, cells were seeded at a density of $5 \times 10^{3}$ cells/well of 96-well cell culture plates. After $24 \mathrm{~h}$ of incubation, cells were serum-starved overnight followed by addition of serum-free medium containing $100 \mathrm{ng} / \mathrm{mL}$ of VEGF and $0.25 \mathrm{mg} / \mathrm{mL}$ of released bevacizumab (test samples) or $0.25 \mathrm{mg} / \mathrm{mL}$ of native bevacizumab (standard). Cells without VEGF or with native bevacizumab treatment were considered as negative control or cells exposed only to VEGF $(100 \mathrm{ng} / \mathrm{mL}$ ) as positive control. Incubation was carried out for $24 \mathrm{~h}$ at $37^{\circ} \mathrm{C}$ and $5 \% \mathrm{CO}_{2}$. Next, cells were exposed to $100 \mu \mathrm{L}$ of serum-free medium containing $20 \mu \mathrm{L}$ of MTS solution and incubated for $4 \mathrm{~h}$. The absorbance was recorded at $450 \mathrm{~nm}$ using a microplate reader.

Cell Migration Assay. A cell migration assay was performed as described elsewhere [30] with few modifications. RF/6A cells were starved overnight (by exposing it to serum-free medium), trypsinized, and suspended in serum-free medium containing $0.25 \mathrm{mg} / \mathrm{mL}$ of bevacizumab (native or released from NPs). Cells $\left(5 \times 10^{3}\right)$ were seeded in upper chamber of Transwell $(8.0 \mu \mathrm{m}$ pore size, $10 \mathrm{~mm}$ diameter, Corning Inc.) and preincubated with cell culture medium. VEGF 
$(100 \mathrm{ng} / \mathrm{mL})$ was placed into the lower chamber and cells were incubated for $24 \mathrm{~h}$ at $37^{\circ} \mathrm{C}$ and $5 \% \mathrm{CO}_{2}$. Nonmigrated cells were removed from upper chamber by cotton swab and concentration of migrated cells was estimated by AlamarBlue assay. It was performed according to supplier's protocol. Moreover, for visual evidence, migrated cells were also stained with methylene blue and images were taken with Leica DMI3000B inverted microscope (Germany). Each experiment was repeated three times.

\section{Results and Discussion}

3.1. Synthesis and Characterization of $P B$ Copolymers. $\mathrm{PB}$ copolymers (PB-A and PB-B) were successfully synthesized by ring-opening bulk copolymerization of $\varepsilon$-caprolactone and L-lactide/glycolide. In the first step, TB copolymers (PCL-PEG-PCL) were synthesized, purified, and characterized as mentioned in the method section. Purified TB copolymers were then utilized for the synthesis of respective $\mathrm{PB}$ copolymers, that is, PB-A (PGA-PCL-PEG-PCL-PGA) and PB-B (PLA-PCL-PEG-PCL-PLA). Purity and molecular weights $(\mathrm{Mn})$ of $\mathrm{PB}$ copolymers were calculated by ${ }^{1} \mathrm{H}$ NMR spectroscopy. As described in Figures 4 and 5, typical ${ }^{1} \mathrm{H}$-NMR signals of PCL blocks were observed at 1.40 , $1.65,2.30$, and $4.06 \mathrm{ppm}$ depicting methylene protons of $-\left(\mathrm{CH}_{2}\right)_{3}-,-\mathrm{OCO}-\mathrm{CH}_{2}-$, and $-\mathrm{CH}_{2} \mathrm{OOC}-$, respectively. $\mathrm{PB}-$ A exhibited cluster of singlets between 4.6 and $4.9 \mathrm{ppm}$ representing methylene protons $\left(-\mathrm{CH}_{2}-\right)$ of PGA units. PB copolymer with PLA units as terminals (PB-B) demonstrated two additional peaks at $1.50\left(-\mathrm{CH}_{3}\right)$ and $5.17(-\mathrm{CH}-)$ ppm. Molar ratios of PB-A and PB-B were calculated from the integration values of PEG (3.65 ppm), PCL (2.30 ppm), and PLA (5.17 ppm) or PGA (4.6-4.9 ppm). ${ }^{1} \mathrm{H}-\mathrm{NMR}$ spectra of PB-C (Figure 6) exhibit typical proton signals of PEG, PCL, and PLA. An additional peak at $3.38 \mathrm{ppm}$ was denoted to terminal methyl of $\left(-\mathrm{OCH}_{3}-\right)$ of PEG and utilized for the molecular weight $(\mathrm{Mn})$ calculation of $\mathrm{PB}-\mathrm{C}$ copolymer. As described in Table 1, polydispersity (PDI) of all the polymers was below 1.45 suggesting narrow distribution of molecular weights. Moreover, block copolymers depicted a single peak in GPC chromatogram (Figure 7) indicating monodistribution of molecular weight and absence of any homopolymers such as PLA, PGA, PCL, and PEG. Molecular weights (Mn) of PB-A, PB-B, and PB-C calculated with ${ }^{1} \mathrm{H}-\mathrm{NMR}$ spectroscopy and GPC were very similar to theoretical molecular weights (Table 1). Therefore, theoretical molecular weights are mentioned instead of calculated molecular weights in this report.

3.2. In Vitro Cytotoxicity Studies. In order to investigate compatibility of $\mathrm{PB}$ polymeric materials with biological system (ocular cell lines), ARPE-19, SIRC, HCEC, and RAW264.7 cells for $48 \mathrm{~h}$ were treated with $10 \mathrm{mg} / \mathrm{mL}$ of PB-A and $\mathrm{PB}-\mathrm{B}$ for $48 \mathrm{~h}$. LDH is a cytoplasmic enzyme, secreted in cell culture medium following cell-membrane damage. Estimation of $\mathrm{LDH}$ concentration in culture supernatant may provide PB copolymer toxicity. Less than $10 \%$ of $\mathrm{LDH}$ release was observed after $48 \mathrm{~h}$ exposure indicating negligible toxicity with any of the ocular cell lines (Figure 8). Noticeably, results were comparable with negative controls.

To further confirm our observation, in addition to LDH assay, MTS cell viability studies were also performed utilizing a similar protocol. In MTS assay, only metabolically active cells convert tetrazolium compound to formazan. Hence, the concentrations of formazan products provide a direct estimation of cell viability. Results in Figure 9 demonstrate that more than $90 \%$ cell viability (for all the cell lines) after $48 \mathrm{~h}$ exposure to polymeric materials suggesting excellent safety profile of block copolymers for ocular applications. No significant difference in cell viability was observed relative to negative control.

3.3. In Vitro Biocompatibility Studies. Many investigators have utilized in vitro cell culture model (RAW-264.7) for the estimation of biocompatibility of polymeric materials intended for human applications. In this study we have examined various cytokines release such as TNF- $\alpha$, IL- 6 , and IL-1 $\beta$ in culture supernatant following $24 \mathrm{~h}$ exposure to PB-A and PB-B copolymers. Samples were analyzed via sandwich ELISA method. Results depicted in Figure 10 indicate release of TNF- $\alpha(\sim 200 \mathrm{pg} / \mathrm{mL})$ in both groups, that is, PB-A and PB-B. However, these values are comparable to negative control (cells without treatment) with no significant difference. Similarly, negligible release of IL- 6 and IL- $1 \beta$ was observed suggesting that these copolymers are safe for human use.

\subsection{Characterization of NPs}

3.4.1. Particle Size and Polydispersity. IgG, FITC-BSA, and bevacizumab-encapsulated PB NPs were prepared by $\mathrm{W}_{1} / \mathrm{O} / \mathrm{W}_{2}$ double emulsion solvent evaporation method. NPs prepared from $\mathrm{PB}$ copolymers were ranging in diameter from 320 to $355 \mathrm{~nm}$ (Table 2). Unimodal size distribution with very narrow polydispersity $(0.273-0.305)$ was noted. No significant effect of polymer composition (PB-A/PBB) or type of protein molecule (IgG/BSA/bevacizumab) was evident on particle size. These results suggest that hydrodynamic diameter of protein therapeutics or polymer composition has no significant effect on particle size or distribution.

3.4.2. Entrapment Efficiency (EE) and Drug Loading (DL). Entrapment efficiency (EE) and drug loading (DL) are highly influenced by various parameters including copolymer composition (hydrophobicity of polymer) and phase volume ratios $\left(\mathrm{W}_{1}, \mathrm{O}\right.$, and $\left.\mathrm{W}_{2}\right)$. In order to understand the effect of hydrophobicity of copolymers on EE and DL, we have prepared and evaluated IgG and FITC-BSA-loaded NPs utilizing PB-A and PB-B. PB-A copolymer comprising PGA (hydrophilic block) is relatively hydrophilic compared to PB-B copolymer comprising PLA (hydrophobic block). As presented in Table 2, encapsulation of IgG or FITC-BSA in PB-A NPs was $\sim 40 \%$ and $\sim 35 \%$, respectively. However, PB-B NPs exhibited significantly higher encapsulation of $\sim 70 \%$ and $\sim 69 \%$ for IgG and FITC-BSA, respectively. This is possibly due to the fact that, during preparation of NPs (solvent 

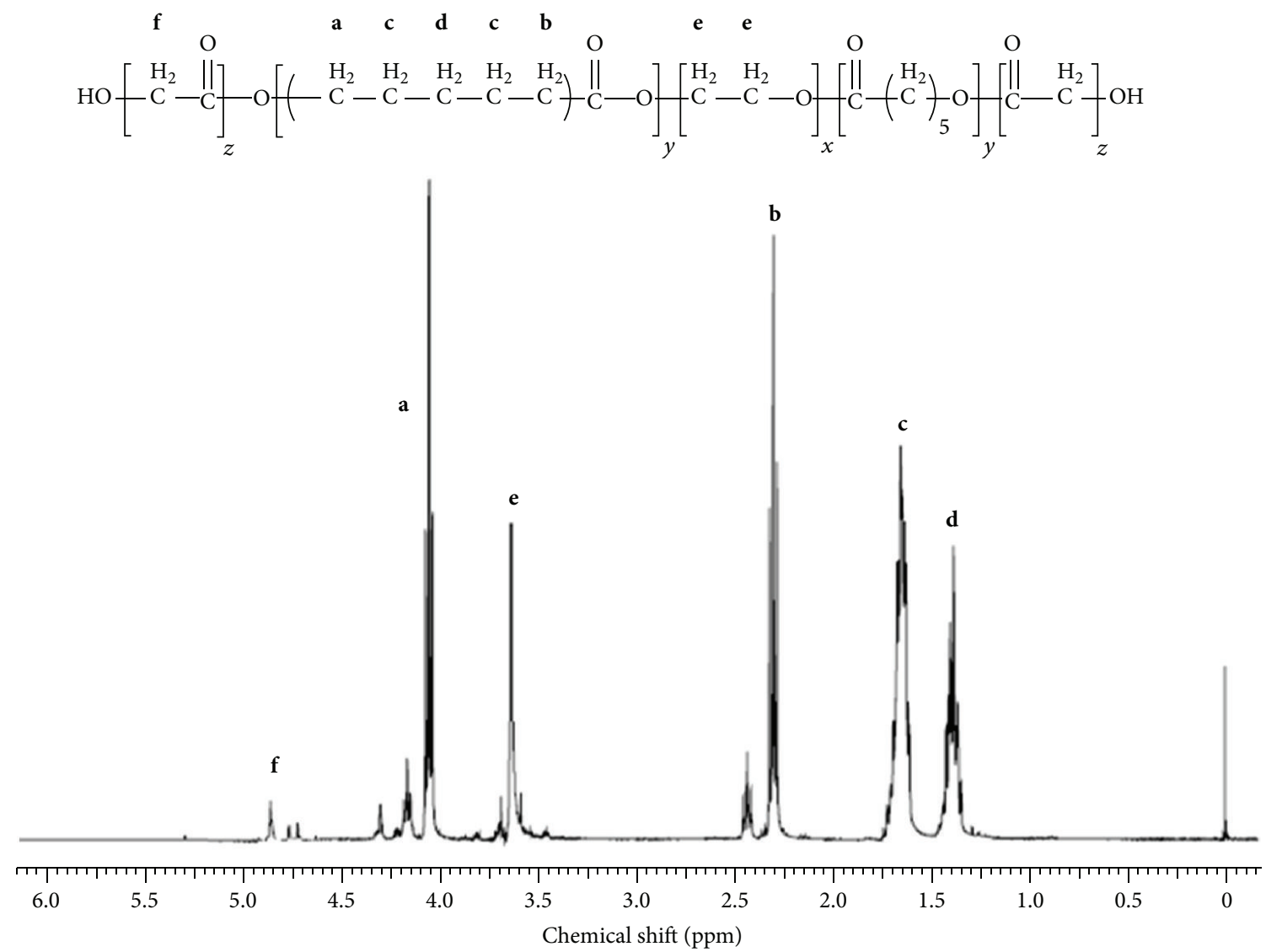

FIgURE $4:{ }^{1} \mathrm{H}$-NMR spectra of PB-A copolymer in $\mathrm{CDCl}_{3}$.

TABLE 1: Characterization of polymers.

\begin{tabular}{|c|c|c|c|c|c|c|}
\hline Code & Structure & $\begin{array}{l}\text { Total } \mathrm{Mn}^{\mathrm{a}} \\
\text { (theoretical) }\end{array}$ & $\begin{array}{l}\text { Total } \mathrm{Mn}^{\mathrm{b}} \\
\text { (calculated) }\end{array}$ & $\begin{array}{l}\text { Total } \mathrm{Mn}^{\mathrm{c}} \\
\text { (calculated) }\end{array}$ & $\begin{array}{l}\mathrm{Mw}^{\mathrm{c}} \\
(\mathrm{GPC})\end{array}$ & $\mathrm{PDI}^{\mathrm{C}}$ \\
\hline PB-A & $\mathrm{PGA}_{300}-\mathrm{PCL}_{7500}-\mathrm{PEG}_{1000}-\mathrm{PCL}_{7500}-\mathrm{PGA}_{300}$ & 16600 & 15705 & 13781 & 18643 & 1.35 \\
\hline PB-B & $\mathrm{PLA}_{3450}-\mathrm{PCL}_{5700}-\mathrm{PEG}_{4000}-\mathrm{PCL}_{5700}-\mathrm{PLA}_{3450}$ & 22300 & 21034 & 19156 & 26978 & 1.41 \\
\hline $\mathrm{PB}-\mathrm{C}$ & $\mathrm{PEG}_{550}-\mathrm{PCL}_{825}-\mathrm{PLA}_{550}-\mathrm{PCL}_{825}-\mathrm{PEG}_{550}$ & 3300 & 2910 & 4227 & 6044 & 1.43 \\
\hline
\end{tabular}

a: theoretical weight of polymer.

b: molecular weight based on H-NMR.

c: molecular weight and PDI based on GPC.

evaporation), hydrophobicity may allow faster precipitation of PB-B copolymer to form NPs preventing diffusion of IgG/FITC-BSA from $\mathrm{W}_{1}$ phase to external aqueous $\left(\mathrm{W}_{2}\right)$ phase. This phenomenon ensured higher EE of protein therapeutics in PB-B NPs. Due to higher hydrophilicity, PBA copolymer may remain hydrated with $\mathrm{W}_{1}$ and $\mathrm{W}_{2}$ phases (during NPs preparation) allowing escape of IgG/FITCBSA in external phase resulting in poor EE. However, no effect of hydrodynamic diameter of IgG or FITC-BSA on $\mathrm{EE}$ or DL was observed. It is very plausible that both of the proteins are too large $(\geq 66 \mathrm{kDa})$ to show any significant effect of hydrodynamic diameter on EE or DL. Bevacizumabloaded PB-B NPs exhibited $\sim 67 \%$ of EE and $\sim 6 \%$ of DL, very similar to IgG-loaded PB-B NPs (Table 2) suggesting that similar molecules behave similarly during NP preparation.
3.4.3. In Vitro Release Studies. In order to evaluate the effect of polymer hydrophobicity, release of FITC-BSA and IgG from PB-A and PB-B NPs was evaluated. As described in Figure 11, both NPs (PB-A and PB-B) demonstrated biphasic release profile, that is, initial burst release followed by sustained release. PB-A NPs exhibited significantly higher burst release $(\sim 56 \%)$ of FITC-BSA relative to PB-B NPs $(\sim 48 \%)$. In the second phase, PB-B NPs provided sustained BSA release for $\sim 36$ days whereas PB-A NPs prolonged the release for only $\sim 27$ days. Similar effect of polymer hydrophobicity was observed with IgG-encapsulated NPs where PB-B NPs displayed longer release ( $\sim 4$ days) than PB-A NPs ( $\sim 30$ days) (Figure 12). As described earlier, PGA based PB-A copolymer is hydrophilic compared to PLA based PB-B copolymer. Therefore, it is anticipated that PBA NPs possibly have higher affinity for the protein molecules 


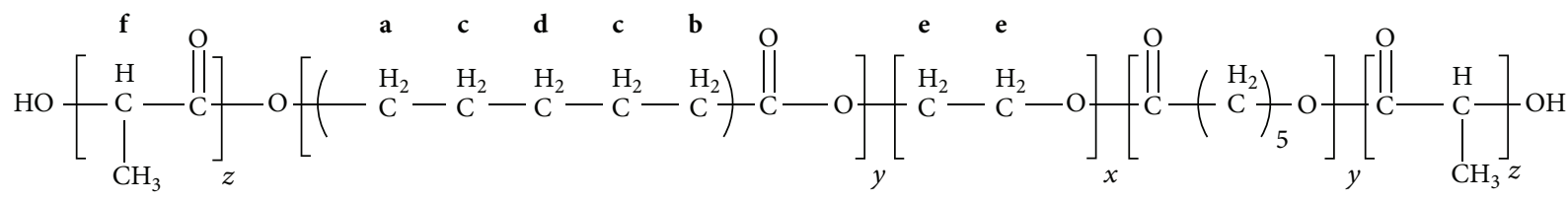

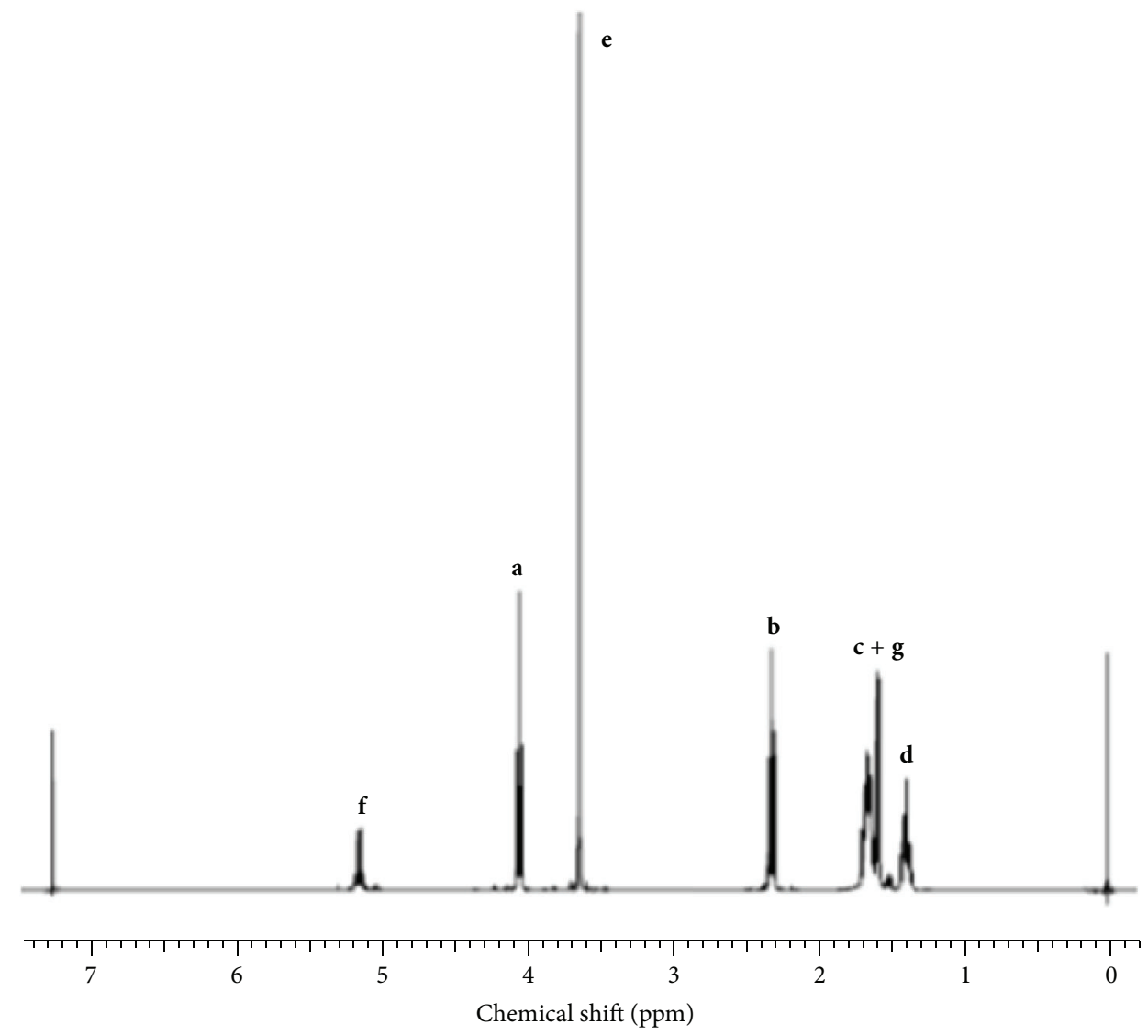

Figure 5: ${ }^{1} \mathrm{H}$-NMR spectra of PB-B copolymer in $\mathrm{CDCl}_{3}$.

TABLE 2: Characterization of FITC-BSA and IgG-loaded NPs.

\begin{tabular}{lccccc}
\hline Proteins & Copolymers & Entrapment efficiency (\%) & Loading (\%) & Particle size & Polydispersity \\
\hline \multirow{2}{*}{ FITC-BSA } & PB-A & $34.98 \pm 3.73$ & $5.02 \pm 0.39$ & $351.5 \pm 30.7$ & 0.286 \\
& PB-B & $69.54 \pm 6.23$ & $5.42 \pm 0.46$ & $323.1 \pm 24.7$ & 0.280 \\
\hline \multirow{2}{*}{ IgG } & PB-A & $40.51 \pm 3.46$ & $6.31 \pm 0.27$ & $367.9 \pm 11.9$ & 0.305 \\
& PB-B & $70.06 \pm 4.12$ & $6.07 \pm 0.31$ & $346.4 \pm 3.9$ & 0.273 \\
\hline Bevacizumab & PB-B & $67.34 \pm 3.28$ & $6.12 \pm 0.22$ & $337.8 \pm 18.4$ & 0.246 \\
\hline
\end{tabular}

Results are described in mean $\pm \mathrm{SD}, n=3$.

TABLE 3: Coefficient of determination $\left(R^{2}\right)$ for various kinetic models for in vitro release of FITC-BSA, IgG, and bevacizumab.

\begin{tabular}{|c|c|c|c|c|c|c|c|}
\hline \multirow{2}{*}{ Block copolymers } & \multicolumn{2}{|c|}{ Korsmeyer-Peppas } & \multirow{2}{*}{$\begin{array}{c}\text { Higuchi } \\
R^{2}\end{array}$} & \multirow{2}{*}{$\begin{array}{c}\text { Hixson-Crowell } \\
R^{2}\end{array}$} & \multirow{2}{*}{$\begin{array}{c}\text { First-order } \\
R^{2}\end{array}$} & \multirow{2}{*}{$\begin{array}{c}\text { Zero-order } \\
R^{2}\end{array}$} & \multirow{2}{*}{ Best fit model } \\
\hline & $R^{2}$ & $n$ & & & & & \\
\hline FITC-BSA PB-B NPs & 0.989 & 0.327 & 0.945 & 0.905 & 0.984 & 0.783 & Korsmeyer-Peppas \\
\hline IgG NPs PB-B NPs & 0.982 & 0.334 & 0.979 & 0.979 & 0.959 & 0.898 & Korsmeyer-Peppas \\
\hline Bevacizumab PB-B NPs & 0.977 & 0.344 & 0.969 & 0.961 & 0.959 & 0.881 & Korsmeyer-Peppas \\
\hline FITC-BSA PB-B NPs suspended in gel & 0.992 & 0.549 & 0.978 & 0.959 & 0.982 & 0.851 & Korsmeyer-Peppas \\
\hline IgG PB-B NPs suspended in gel & 0.997 & 0.818 & 0.971 & 0.996 & 0.987 & 0.994 & Korsmeyer-Peppas \\
\hline
\end{tabular}




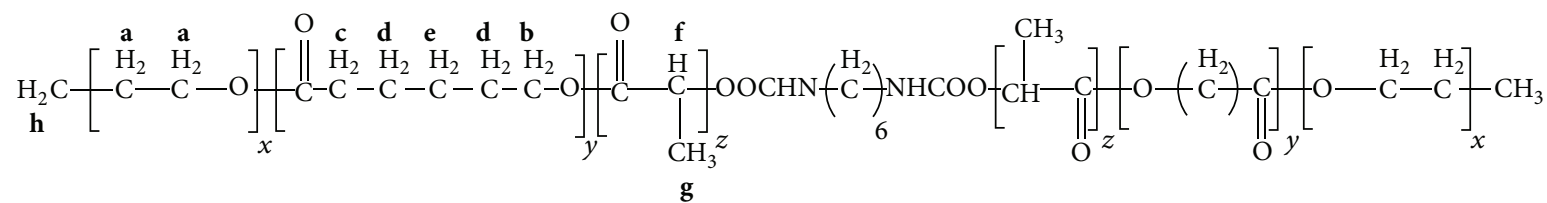

a

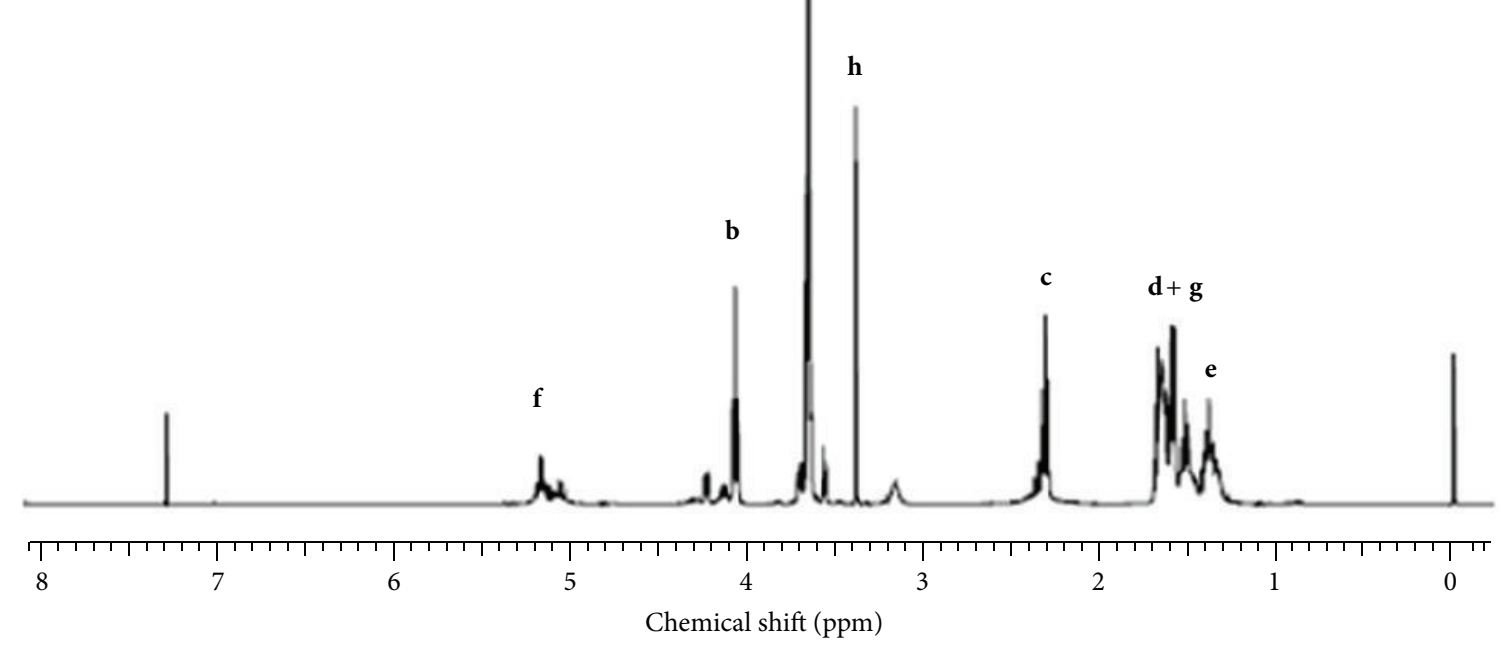

Figure 6: ${ }^{1} \mathrm{H}-\mathrm{NMR}$ spectra of PB-C copolymer in $\mathrm{CDCl}_{3}$.

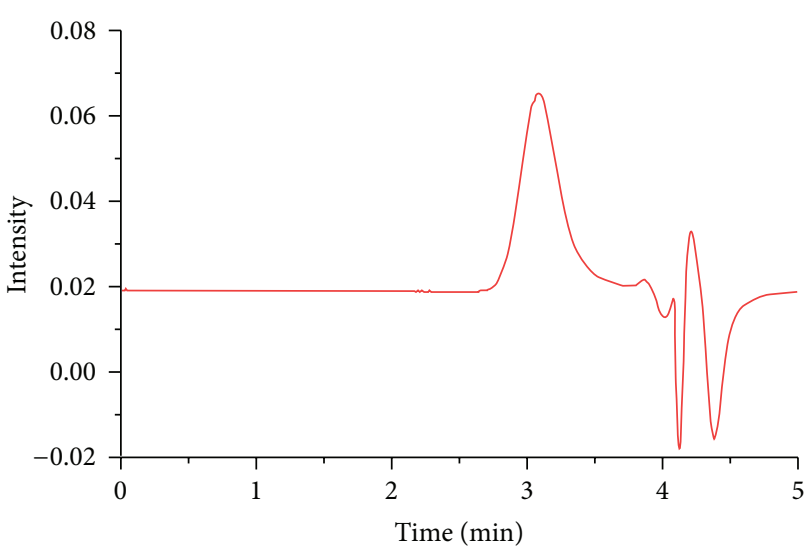

FIGURE 7: Gel permeation chromatogram of PB-A copolymer.

which may result in higher amount of surface adsorbed drug. Moreover, being hydrophilic, PB-A NPs may be easily hydrated which may allow rapid diffusion of water molecules through polymeric matrix. Therefore, higher amounts of surface adsorbed proteins and higher affinity towards water molecules may have contributed to the higher burst release and shorter duration of release from in PB-A NPs.

Hydrodynamic diameter of protein therapeutics may have significant effect on drug release pattern. In order to examine this possibility we have compared in vitro release profiles of FITC-BSA $(66 \mathrm{kDa})$ and IgG $(150 \mathrm{kDa})$ (Figure 13) from PB-B NPs. Results indicate significantly higher burst release and shorter release duration for FITC-BSA relative to IgG from their respective NPs. FITC-BSA has smaller hydrodynamic diameter compared to IgG and may lead to more rapid diffusion through the polymeric matrix of NPs. To further confirm this hypothesis, we have compared in vitro release profile of IgG and bevacizumab $(149 \mathrm{kDa})$ from their respective PB-B NPs. Figure 14 suggests no significant difference between the release profile of IgG and bevacizumab. Since IgG and bevacizumab are full-length antibodies with similar hydrophilicity and molecular weight (hydrodynamic diameter), both protein molecules behave similarly during NPs preparation and during release. These results suggest that 


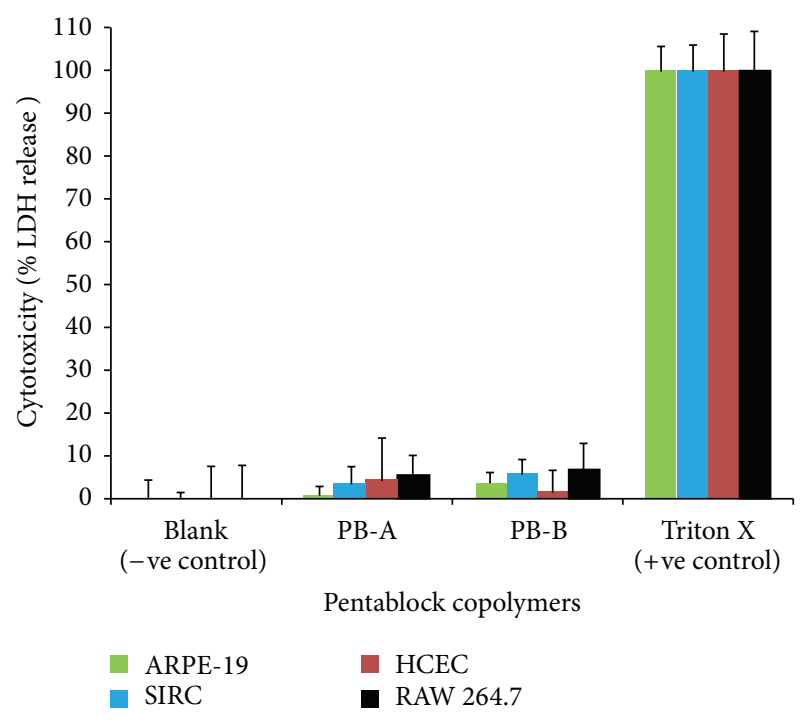

FIGURE 8: In vitro cytotoxicity assay (LDH) of PB-A and PB$B$ copolymers at the concentration of $10 \mathrm{mg} / \mathrm{mL}$ was performed on ARPE-19, SIRC, HCEC, and RAW-264.7 cell lines. Results are described in mean $\pm \mathrm{SD}, n=6$.

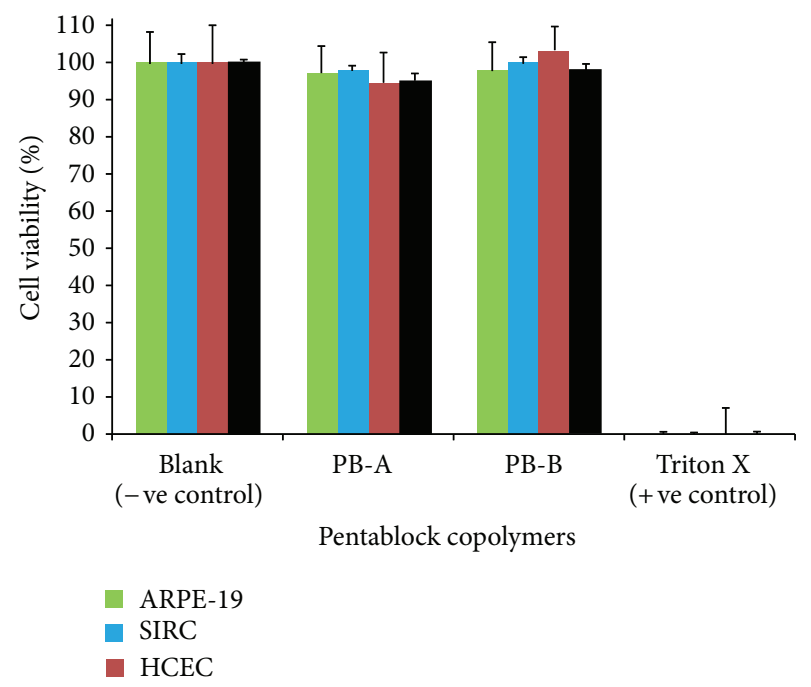

Figure 9: In vitro cell viability assay (MTS) of PB-A and PB$B$ copolymers at the concentration of $10 \mathrm{mg} / \mathrm{mL}$ was performed on ARPE-19, SIRC, HCEC, and RAW-264.7 cell lines. Results are described in mean $\pm \mathrm{SD}, n=6$.

parallel molecules (IgG or bevacizumab) may not generate any difference in drug release pattern whereas there is a significant effect of hydrodynamic diameter (FITC-BSA or $\operatorname{IgG}$ ) on drug release.

Protein molecules exhibit high specificity and require very low dose to exert therapeutic activity. Any nanoparticulate or microparticulate system can have certain amount of surface adsorbed drug, which is released within the first $24 \mathrm{~h}$ leading to burst effect. Being very potent by nature, burst release of protein therapeutics may produce side effects. Therefore, pharmaceutical scientists are focused on

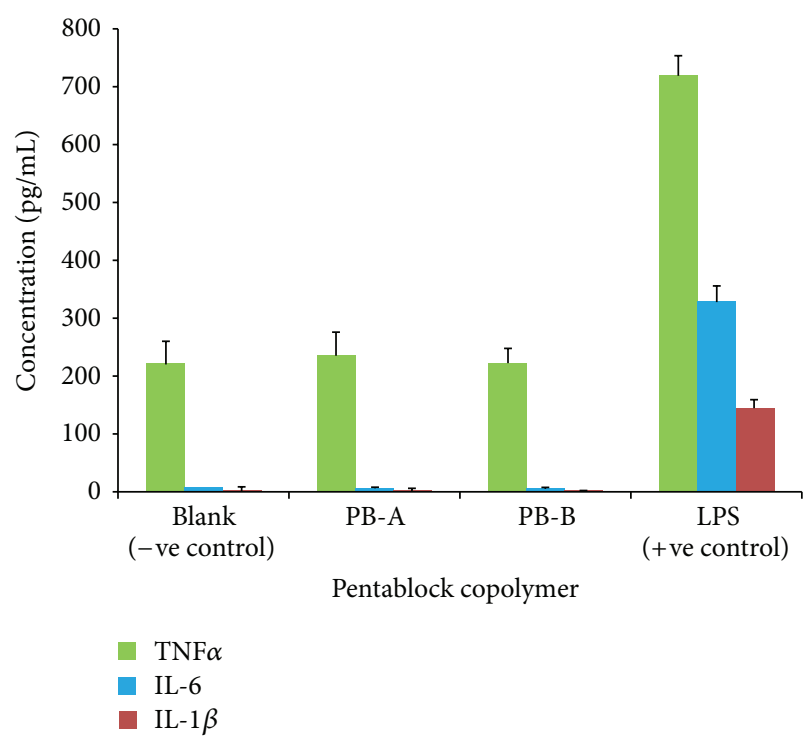

FIGURE 10: In vitro biocompatibility of PB-A and PB-B copolymers was evaluated by estimating the levels of TNF- $\alpha$, IL- 6 , and IL- $1 \beta$ in the supernatants of polymer treated RAW 264.7 cells. Results are described in mean $\pm \mathrm{SD}, n=6$.

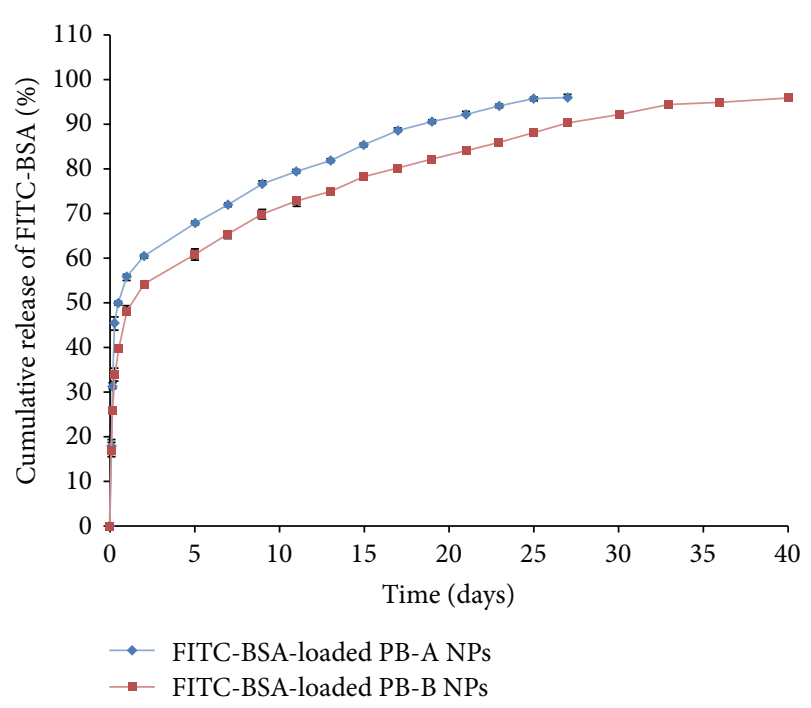

FIGURE 11: In vitro release of FITC-BSA from NPs prepared with PB$\mathrm{A}$ and PB-B copolymers. Results are described in mean $\pm \mathrm{SD}, n=3$.

developing a formulation which can eliminate or minimize burst effect and offer zero-order drug release throughout the release period. In order to achieve zero-order drug release profile, protein-encapsulated PB-B NPs were suspended in an aqueous solution of thermosensitive gelling polymer (PB-C). Thermosensitive gelling solution was composed of $20 \mathrm{wt} \%$ PB-C copolymer in DDW. Aqueous solution of PB-C copolymer remains in liquid state around room temperature but immediately transforms to hydrogel at body temperature (sol-gel transition).

Protein-loaded NPs were suspended in $20 \mathrm{wt} \%$ gelling solution and then brought to $37^{\circ} \mathrm{C}$ which immediately 


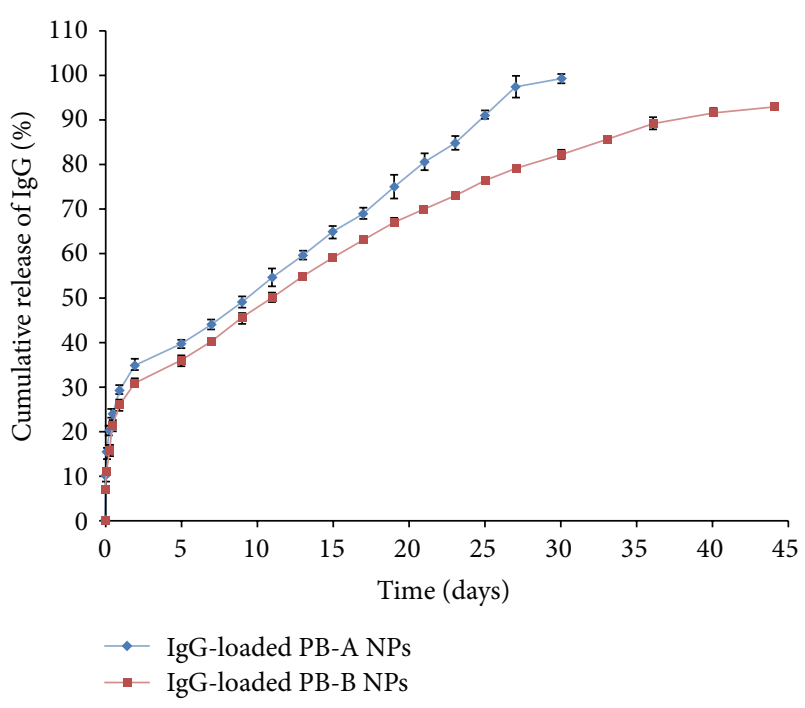

FIGURE 12: In vitro release of IgG from NPs prepared with PB-A and $\mathrm{PB}-\mathrm{B}$ copolymers. Results are described in mean $\pm \mathrm{SD}, n=3$.

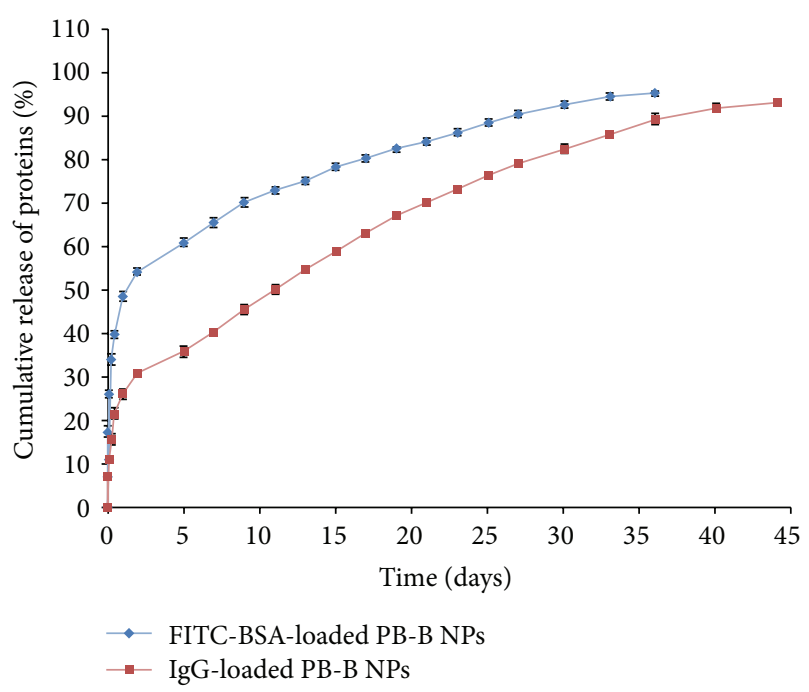

FIGURE 13: In vitro release of FITC-BSA and IgG from PB-B NPs. Results are described in mean $\pm \mathrm{SD}, n=3$.

transitioned the solution to solid hydrogel entrapping NPs throughout the polymeric matrix. These composite formulations comprised of protein-loaded PB-B NPs (FITC-BSA and $\operatorname{IgG}$ ) suspended in thermosensitive gel were evaluated for release pattern. As depicted in Figure 15, burst release of FITC-BSA from composite formulation was negligible ( $10 \%)$ relative to burst release observed from PB-B NPs ( $48 \%)$. In addition, release of FITC-BSA was prolonged over 40 days. A similar pattern was also observed for a composite formulation comprising IgG-loaded PB-B NPs suspended in $20 \mathrm{wt} \%$ thermosensitive gelling solution (Figure 16). Composite formulation of IgG exhibited negligible burst release followed by zero-order release up to 60 days. This behavior may be due to the fact that when the NPs were suspended into the gel matrix the matrix serves as an additional diffusion barrier for the surface adsorbed drug. The gel matrix might

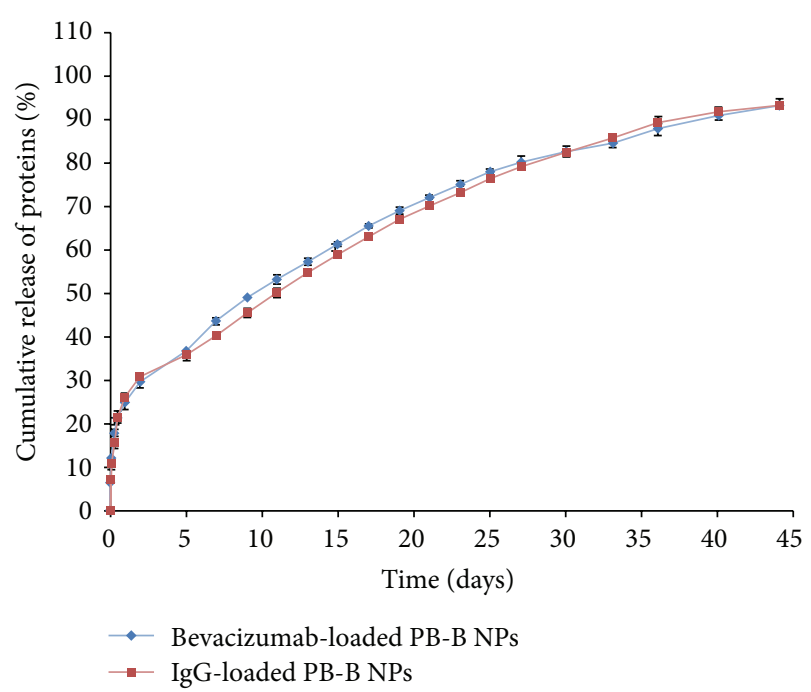

FIGURE 14: In vitro release of IgG and bevacizumab from PB-B NPs. Results are described in mean $\pm \mathrm{SD}, n=3$.

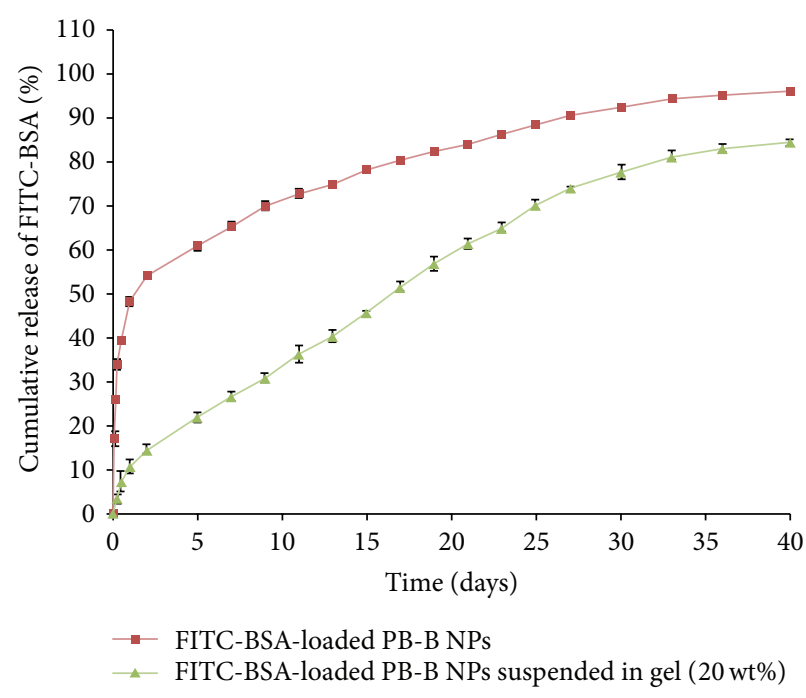

FIGURE 15: In vitro release of FITC-BSA from PB-B NPs and PB-B NPs suspended in PB-C gelling polymer. Results are described in mean $\pm \mathrm{SD}, n=3$.

deter quick hydration and dumping of surface adsorbed dose eliminating burst effect. It also leads to zero-order drug release throughout the release period.

3.5. Release Kinetics. In order to evaluate drug release mechanism, we have fitted in vitro drug release data in five different release kinetic models, that is, Korsmeyer-Peppas, Higuchi, Hixson-Crowell, zero-order, and first-order models. Results, presented in Table 3, indicate that Korsmeyer-Peppas is the best fit model for all the formulations with $R^{2}$ values ranging between 0.977 and 0.997 . Moreover, $n$ values in Korsmeyer-Peppas model for release of FITC-BSA, IgG, and bevacizumab from PB-B NPs were below 0.43 indicating diffusion controlled release. Interestingly, $n$ values for composite formulation of FITC-BSA (0.549) and IgG (0.818) 


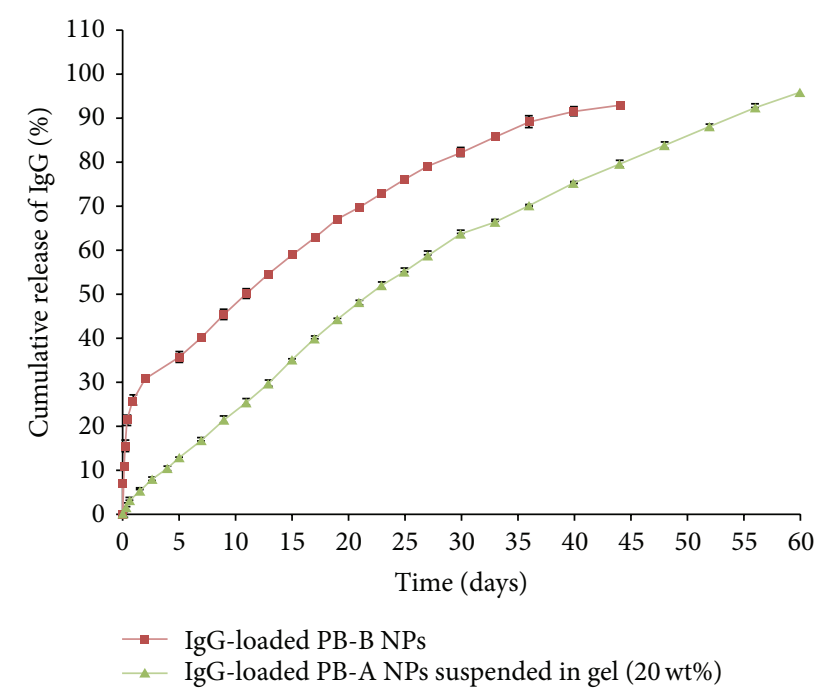

Figure 16: In vitro release of IgG from PB-B NPs and PB-B NPs suspended in $\mathrm{PB}-\mathrm{C}$ gelling polymer. Results are described in mean $\pm \mathrm{SD}, n=3$.

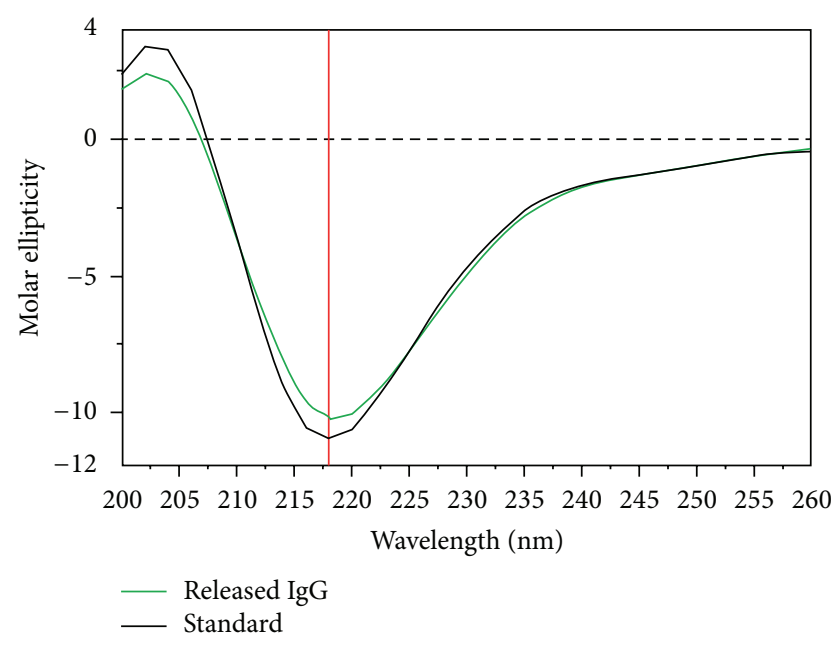

FIGURE 17: Stability of released IgG confirmed by CD spectroscopy.

(NPs suspended in thermosensitive gel) were between 0.43 and 0.89 suggesting anomalous diffusion. In other words, release of protein therapeutics from composite formulation is controlled by diffusion as well as degradation of polymer.

3.6. Stability of Secondary Structure of IgG. Protein molecules need to maintain three-dimensional structure to retain biological activity. CD spectroscopy is a sensitive and robust analytical technique exploited for the investigation of secondary and to some extent tertiary conformation of proteins. It is sensitive enough to detect minor conformational changes in $\alpha$-helix and $\beta$-sheets of the protein. Therefore, we have utilized this technique to confirm the conformational stability of released IgG by comparing with $\mathrm{CD}$ spectrum of native IgG (Figure 17). CD spectrum of released IgG demonstrated $\lambda$ minima of $218 \mathrm{~nm}$ similar to the native IgG. In addition, CD spectra of native and released IgG ranging from $200 \mathrm{~nm}$ to $250 \mathrm{~nm}$ were identical indicating retention of protein conformation during NP preparation and after release.

3.7. Cell Proliferation Assay. A cell proliferation assay was performed as described previously [29]. RF/6A cells proliferated rapidly in presence of VEGF $(100 \mathrm{ng} / \mathrm{mL}$, +ve control). However, proliferation was inhibited in absence of VEGF indicating sensitivity of endothelial cells towards growth factor, particularly, VEGF (Figure 18). Native bevacizumab (standard group) strongly inhibited VEGF-induced cell proliferation at a concentration of $0.25 \mathrm{mg} / \mathrm{mL}$. A similar level of inhibition was also observed when released (from NPs) bevacizumab (test/sample group) was exposed for $24 \mathrm{~h}$ to VEGF treated cells. Moreover, inhibitory effects of released and native bevacizumab were not significantly different than - ve control.

3.8. Cell Migration Assay. VEGF carries chemoattractant property which stimulates migration of RF/6A cells across a porous membrane towards a VEGF stimulus. Biological activity of released bevacizumab was further evaluated by VEGF-induced cell migration assay. As described in Figure 19, a test/sample group (released bevacizumab) exhibited significant inhibition of cell migration across transwell membrane compared to VEGF treated group (+ve control). Results indicated that this inhibitory effect was not significantly different than -ve control or a standard group (cells treated with native bevacizumab). For visual evidence, migrated cells were stained with methylene blue and images were prepared. Figure 19(b) also supports the results described earlier.

Cell proliferation and migration assays clearly suggest that bevacizumab activity is retained during NP preparation and release. Previous reports suggest that PLA and/or PGA based copolymers produce large molar mass of lactic acid and/or glycolic acid [16, 17]. These degradation products stimulate hydrolytic degradation of protein therapeutics. Retention of protein stability (IgG and bevacizumab) in PB NPs can be attributed to lower molar mass of PLA or PGA blocks which produce very low amounts of lactic acid or glycolic acid, thereby eliminating or reducing the possibilities of protein degradation.

\section{Conclusion}

This research article discusses synthesis and characterization of novel PB copolymers for the preparation of NPs and thermosensitive gel. In order to eliminate burst release phase, a novel composite formulation comprised of proteinloaded PB NPs suspended in PB thermosensitive gel was successfully formulated and evaluated. FITC-BSA and IgG-encapsulated NPs suspended in thermosensitive gel demonstrated continuous zero-order release avoiding any possibility of dose-dependent toxicity. Bevacizumab-loaded NPs without gel demonstrated the same patterns of burst release and sustained release as those of IgG-embedded NPs. Retention of functional activity of bevacizumab by in vitro cell proliferation and migration suggests that this approach 


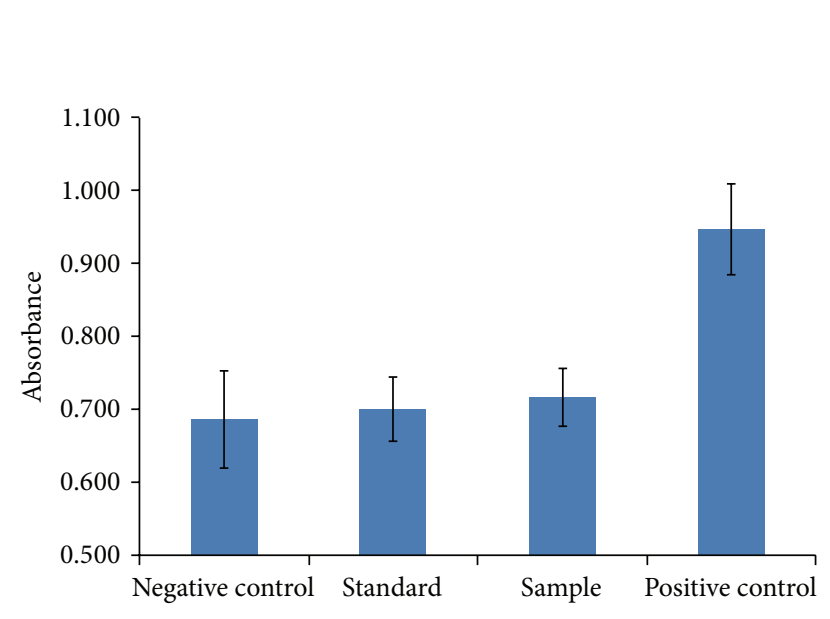

(a)
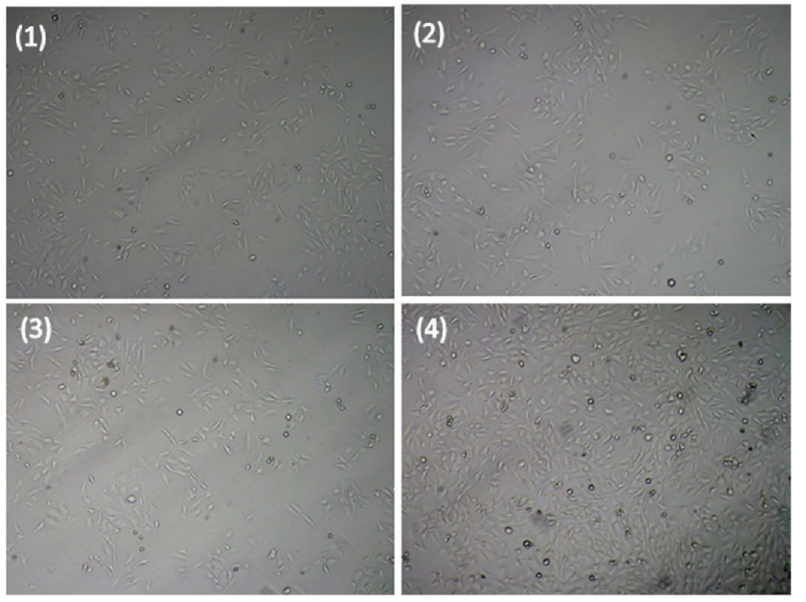

(b)

FIGURE 18: Cell proliferation assay performed on RF/6A cells to evaluate the biological activity of bevacizumab (a) absorbance produced by live cells, (b) images of live cells including (1) negative control (untreated cells), (2) standard (cells exposed to $100 \mathrm{ng} / \mathrm{mL}$ of VEGF and $0.25 \mathrm{mg} / \mathrm{mL}$ of bevacizumab), (3) sample (cells exposed to $100 \mathrm{ng} / \mathrm{mL}$ of VEGF and $0.25 \mathrm{mg} / \mathrm{mL}$ of released bevacizumab), and (4) positive control (cell exposed to $100 \mathrm{ng} / \mathrm{mL}$ VEGF). Results are described in mean $\pm \mathrm{SD}, n=6$.

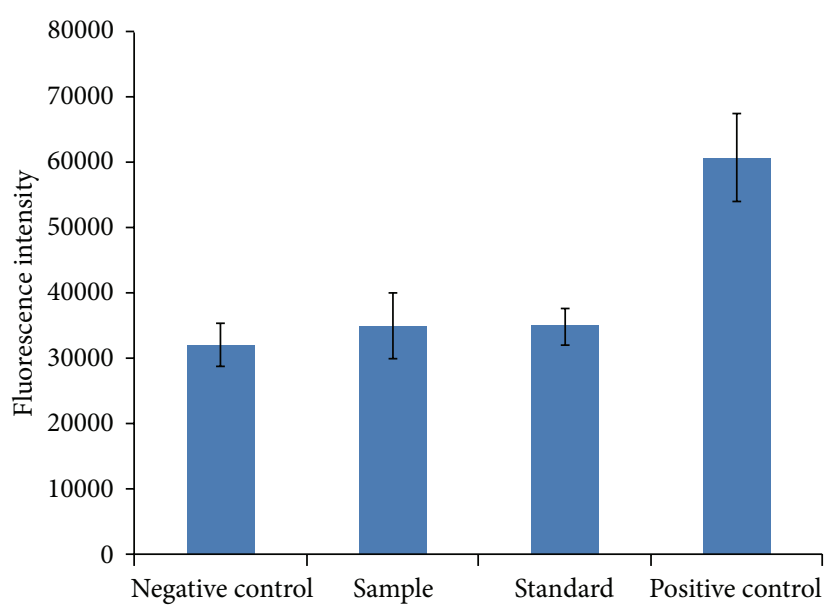

(a)
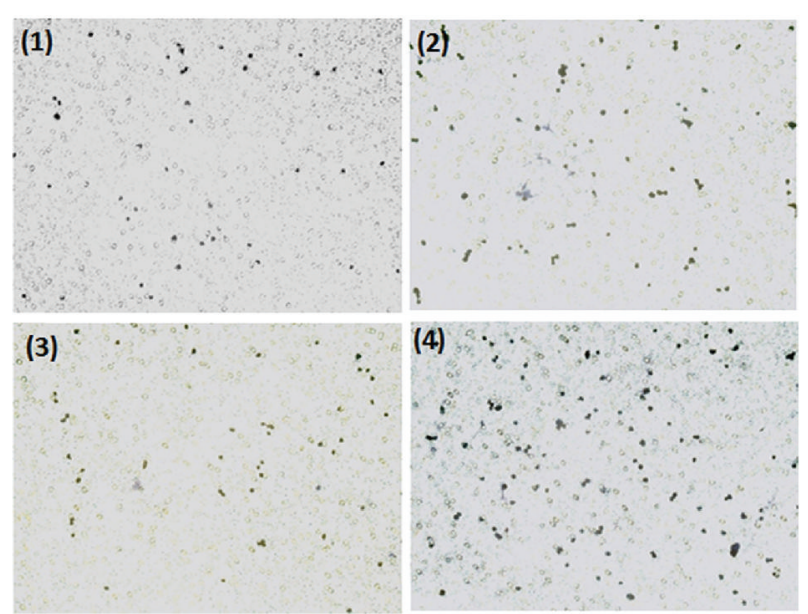

(b)

FIGURE 19: Cell migration assay performed on RF/6A cells to evaluate the biological activity of bevacizumab (a) fluorescence intensity indicating number of migrated cells, (b) images of migrated cells stained by methylene blue including (1) negative control (untreated cells), (2) standard (cells exposed to $100 \mathrm{ng} / \mathrm{mL}$ of VEGF and $0.25 \mathrm{mg} / \mathrm{mL}$ of bevacizumab), (3) sample (cells exposed to $100 \mathrm{ng} / \mathrm{mL}$ of VEGF and $0.25 \mathrm{mg} / \mathrm{mL}$ of released bevacizumab), and (4) positive control (cell exposed to $100 \mathrm{ng} / \mathrm{mL}$ VEGF). Results are described in mean \pm SD, $n=6$.

can act as a platform for the ocular delivery of therapeutic macromolecules. Such a system can minimize side effects associated with frequent intravitreal injections.

\section{Conflict of Interests}

The authors declare that they have conflict of interests with I-Novion Inc. and Genentech Inc.

\section{Acknowledgments}

This study was supported by NIH R01 EY09171-14 and NIH RO1 EY10659-12. The authors are greatly thankful to Dr.
Zhonghua Peng (Department of Chemistry, UMKC) for his assistance in GPC analysis, Dr. Kun Cheng (Department of Pharmaceutical Sciences, UMKC) for allowing them to utilize inverted microscope for imaging and freeze-dryer, and Dr. Natalya Shipulina (School of Biological Sciences, UMKC) for helping in CD spectroscopy analysis.

\section{References}

[1] A. D. Kulkarni and B. D. Kuppermann, "Wet age-related macular degeneration," Advanced Drug Delivery Reviews, vol. 57, no. 14, pp. 1994-2009, 2005. 
[2] D. W. Leung, G. Cachianes, W. Kuang, D. V. Goeddel, and N. Ferrara, "Vascular endothelial growth factor is a secreted angiogenic mitogen," Science, vol. 246, no. 4935, pp. 1306-1309, 1989.

[3] B. T. Ozturk, H. Kerimoglu, B. Bozkurt, and S. Okudan, "Comparison of intravitreal bevacizumab and ranibizumab treatment for diabetic macular edema," Journal of Ocular Pharmacology and Therapeutics, vol. 27, no. 4, pp. 373-377, 2011.

[4] S. J. Bakri, M. R. Snyder, J. M. Reid, J. S. Pulido, and R. J. Singh, "Pharmacokinetics of intravitreal bevacizumab (Avastin)," Ophthalmology, vol. 114, no. 5, pp. 855-859, 2007.

[5] K. M. Sampat and S. J. Garg, "Complications of intravitreal injections," Current Opinion in Ophthalmology, vol. 21, no. 3, pp. 178-183, 2010.

[6] R. D. Jager, L. P. Aiello, S. C. Patel, and E. T. Cunningham Jr., "Risks of intravitreous injection: a comprehensive review," Retina, vol. 24, no. 5, pp. 676-698, 2004.

[7] G. A. Peyman, E. M. Lad, and D. M. Moshfeghi, "Intravitreal injection of therapeutic agents," Retina, vol. 29, no. 7, pp. 875912, 2009.

[8] V. Pourcelle, S. Devouge, M. Garinot, V. Préat, and J. MarchandBrynaert, "PCL-PEG-based nanoparticles grafted with GRGDS peptide: preparation and surface analysis by XPS," Biomacromolecules, vol. 8, no. 12, pp. 3977-3983, 2007.

[9] W. Jia, Y. Gu, M. Gou et al., "Preparation of biodegradable polycaprolactone/poly (ethylene glycol)/polycaprolactone (PCEC) nanoparticles," Drug Delivery, vol. 15, no. 7, pp. 409-416, 2008.

[10] U. Bilati, E. Allémann, and E. Doelker, "Poly(D,L-lactideco-glycolide) protein-loaded nanoparticles prepared by the double emulsion method-processing and formulation issues for enhanced entrapment efficiency," Journal of Microencapsulation, vol. 22, no. 2, pp. 205-214, 2005.

[11] S. H. Lee, Z. Zhang, and S. S. Feng, "Nanoparticles of poly(lactide)-tocopheryl polyethylene glycol succinate (PLATPGS) copolymers for protein drug delivery," Biomaterials, vol. 28, no. 11, pp. 2041-2050, 2007.

[12] T. R. Kumar, K. Soppimath, and S. K. Nachaegari, "Novel delivery technologies for protein and peptide therapeutics," Current Pharmaceutical Biotechnology, vol. 7, no. 4, pp. 261-276, 2006.

[13] S. D. Putney, "Encapsulation of proteins for improved delivery," Current Opinion in Chemical Biology, vol. 2, no. 4, pp. 548-552, 1998.

[14] C. Perez, I. J. Castellanos, H. R. Costantino, W. Al-Azzam, and K. Griebenow, "Recent trends in stabilizing protein structure upon encapsulation and release from bioerodible polymers," Journal of Pharmacy and Pharmacology, vol. 54, no. 3, pp. 301313, 2002.

[15] M. van de Weert, W. E. Hennink, and W. Jiskoot, "Protein instability in poly(lactic-co-glycolic acid) microparticles," Pharmaceutical Research, vol. 17, no. 10, pp. 1159-1167, 2000.

[16] Y. Zhang and S. P. Schwendeman, "Minimizing acylation of peptides in PLGA microspheres," Journal of Controlled Release, vol. 162, no. 1, pp. 119-126, 2012.

[17] E. Zabłotna, A. Jaśkiewicz, A. Łegowska, H. Miecznikowska, A. Lesner, and K. Rolka, "Design of serine proteinase inhibitors by combinatorial chemistry using trypsin inhibitor SFTI-1 as a starting structure," Journal of Peptide Science, vol. 13, no. 11, pp. 749-755, 2007.
[18] K. Fu, D. W. Pack, A. M. Klibanov, and R. Langer, "Visual evidence of acidic environment within degrading poly(lactic-coglycolic acid) (PLGA) microspheres," Pharmaceutical Research, vol. 17, no. 1, pp. 100-106, 2000.

[19] H. Sah, "Stabilization of proteins against methylene chloride/water interface-induced denaturation and aggregation," Journal of Controlled Release, vol. 58, no. 2, pp. 143-151, 1999.

[20] J. Wang, K. M. Chua, and C. H. Wang, "Stabilization and encapsulation of human immunoglobulin $\mathrm{G}$ into biodegradable microspheres," Journal of Colloid and Interface Science, vol. 271, no. 1, pp. 92-101, 2004.

[21] M. Gou, C. Gong, J. Zhang et al., "Polymeric matrix for drug delivery: honokiol-loaded PCL-PEG-PCL nanoparticles in PEG-PCL-PEG thermosensitive hydrogel," Journal of Biomedical Materials Research A, vol. 93, no. 1, pp. 219-226, 2010.

[22] J. Jwala, R. K. Vadlapatla, A. D. Vadlapudi, S. H. S. Boddu, D. Pal, and A. K. Mitra, "Differential expression of folate receptoralpha, sodium-dependent multivitamin transporter, and amino acid transporter $(\mathrm{B}(0,+))$ in human retinoblastoma (Y-79) and retinal pigment epithelial (ARPE-19) cell lines," Journal of Ocular Pharmacology and Therapeutics, vol. 28, no. 3, pp. 237244, 2012.

[23] S. Du, Q. Zhang, S. Zhang, L. Wang, and J. Lian, "Heat shock protein 70 expression induced by diode laser irradiation on choroid-retinal endothelial cells in vitro," Molecular Vision, vol. 18, pp. 2380-2387, 2012.

[24] V. Bhardwaj, D. D. Ankola, S. C. Gupta, M. Schneider, C. Lehr, and M. N. V. R. Kumar, "PLGA nanoparticles stabilized with cationic surfactant: safety studies and application in oral delivery of paclitaxel to treat chemical-induced breast cancer in rat," Pharmaceutical Research, vol. 26, no. 11, pp. 2495-2503, 2009.

[25] S. Basu, R. Harfouche, S. Soni, G. Chimote, R. A. Mashelkar, and S. Sengupta, "Nanoparticle-mediated targeting of MAPK signaling predisposes tumor to chemotherapy", Proceedings of the National Academy of Sciences of the United States of America, vol. 106, no. 19, pp. 7957-7961, 2009.

[26] Q. T. Shubhra, T. Feczko, A. F. Kardos et al., "Co-encapsulation of human serum albumin and superparamagnetic iron oxide in PLGA nanoparticles: part II. Effect of process variables on protein model drug encapsulation efficiency," Journal of Microencapsulation, vol. 31, no. 2, pp. 156-165, 2014.

[27] H. Mu, R. Ohashi, S. Yan et al., "Adipokine resistin promotes in vitro angiogenesis of human endothelial cells," Cardiovascular Research, vol. 70, no. 1, pp. 146-157, 2006.

[28] A. Kasai, N. Shintani, M. Oda et al., "Apelin is a novel angiogenic factor in retinal endothelial cells," Biochemical and Biophysical Research Communications, vol. 325, no. 2, pp. 395-400, 2004.

[29] Y. Xu, H. Zhao, Y. Zheng, Q. Gu, J. Ma, and X. Xu, "A novel antiangiogenic peptide derived from hepatocyte growth factor inhibits neovascularization in vitro and in vivo," Molecular Vision, vol. 16, pp. 1982-1995, 2010.

[30] W. Yu, H. Zou, X. X. Li, Z. Yan, and J. Q. Dong, "Effects of the phosphatidylinositol 3-kinase inhibitor in a mouse model of retinal neovascularization," Ophthalmic Research, vol. 40, no. 1, pp. 19-25, 2007. 

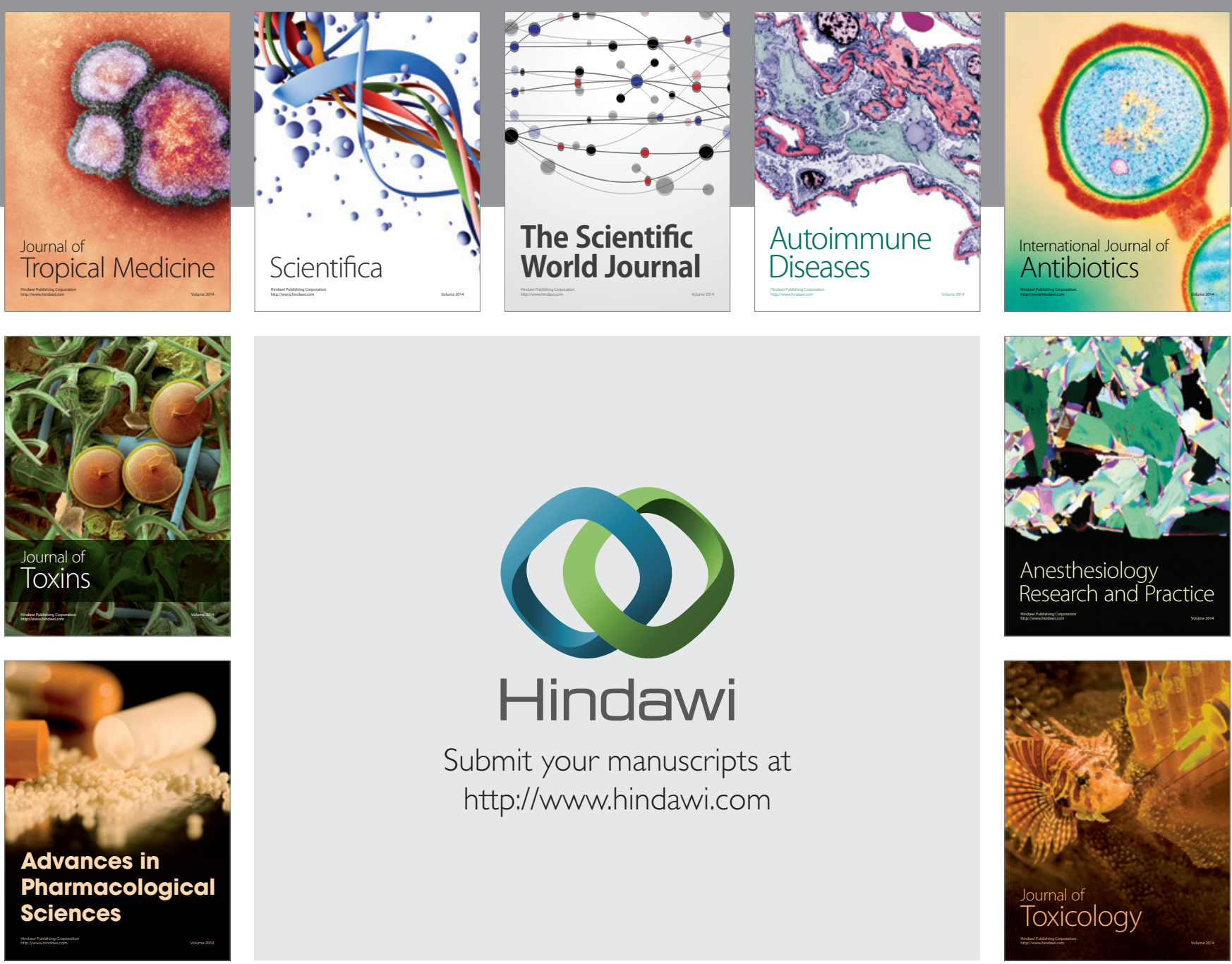

\section{Hindawi}

Submit your manuscripts at

http://www.hindawi.com
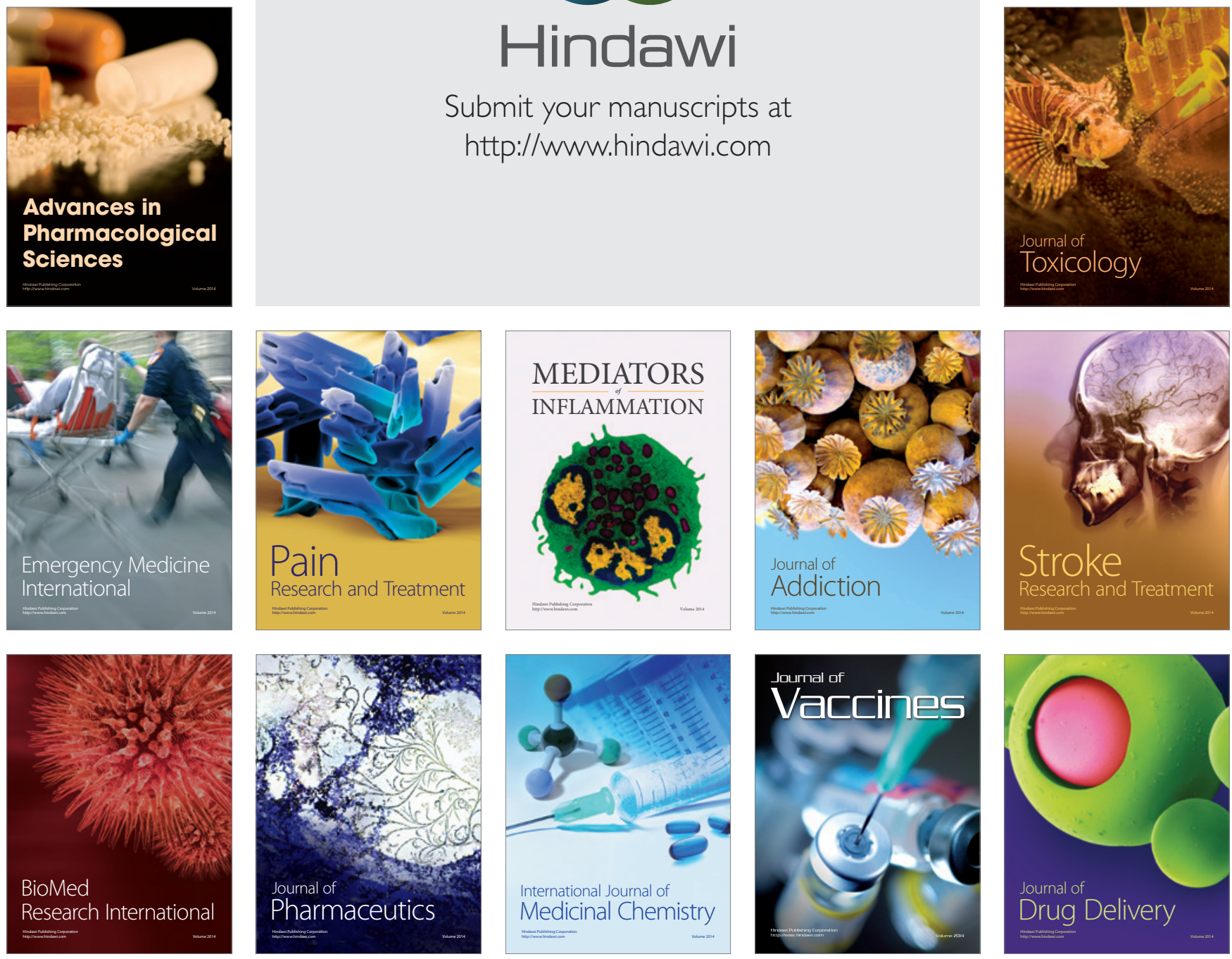